\title{
Yerel Halkın Alternatif Bir Turizm Türü Olarak Heliski Turizmine Yönelik Algısının Heliski Turizmi Desteğine Etkisi: Rize Örneği*
}

(Araştırma Makalesi)

The Effect of Local People's Perception of Heliski Tourism as an Alternative Type of Tourism on Heliski Tourism Support: The Case of Rize Doi: 10.29023/alanyaakademik.987263

\section{Elif ACUNER}

Dr. Öğr. Üyesi, Recep Tayyip Erdoğan Üniversitesi Ardeşen Turizm Fakültesi Turizm Işsletmeciliği Bölümü Ögretim Üyesi,

elif.acuner@erdogan.ed.tr

Orcid No: 0000-0002-7769-8705.

\section{Ersin Uğur AYDIN}

Yüksek Lisans Öğrencisi, Recep Tayyip Erdoğan Üniversitesi Lisansüstü Eğitim Enstitüsü

Turizm Issletmeciliği Anabilim Dall,

ersinugur_aydin20@erdogan.ed.tr

Orcid No: 0000-0003-3382-157X.

Bu makaleye atıfta bulunmak için: Acuner, E. \& Aydın E. U., (2022). "Yerel Halkın Alternatif Bir Turizm Türü Olarak Heliski Turizmine Yönelik Algısının Heliski Turizmi Desteğine Etkisi: Rize Örneği”, Alanya Akademik Bakış, 6(1), Sayfa No. 1757-1781.

\section{ÖZET}

Anahtar kelimeler: Yerel Halk, Turizm Algisl, Turizm Gelişimi, Heliski Turizmi, Rize.

Makale Geliş Tarihi: 25.08.2021 Kabul Tarihi: 21.01.2022

\begin{abstract}
Bu araştırmada Rize'de ikamet eden yerel halkın heliski turizminin gelişimine bağlı olarak ortaya çıkan pozitif etkilere yönelik algısı ve bu algıların heliski turizminin gelişimine verdikleri destek üzerindeki etkisini belirlemek amaçlanmıştır. Araştırma yöntembilimin üç ana yaklaşımı içerisinde yer alan nicel araştırma yöntemi ile yapılandırılmıştır. Araştırmanın teorik alt yapısı sosyal değişim teorisine dayandırılmaktadır. Araştırma verileri kolayda örnekleme yöntemi kullanılarak anket tekniği ile Rize'de ikamet eden yerel halkın görüşleri alınarak elde edilmiştir. Hatalı ve eksik anketler çıkartılarak 400 anket analize tabi tutulmuştur. Araştırma sonuçlarına göre heliski turizminin sosyo-kültürel pozitif ve ekonomik pozitif etkileri ile heliski turizmi gelişimine verilen destek arasında yüksek düzeyde, pozitif ve anlaml,; çevresel pozitif etkiler ile heliski turizminin gelişimine verilen destek arasinda negatif bir ilişki olduğu görülmüştür. Heliski turizmine verilen desteği etkileyen ekonomik, sosyo-kültürel ve çevresel boyut arasından en önemli görülen ekonomik boyut olurken, heliski turizmi desteğini olumsuz yönde etkileyen unsurun ise, çevresel boyut olduğu belirlenmiştir.
\end{abstract}

\section{ABSTRACT}

\footnotetext{
* Bu çalışma için Recep Tayyip Erdoğan Üniversitesi Sosyal ve Beşeri Bilimler Etik Kurulu'nun 30.03.2021 tarihli ve 2021/85 sayılı kararınca "Etik Kurul Onayı" alınmıştır.
} 
Keywords:

Local People,

Tourism Perception,

Tourism

Development,

Heliski Tourism,

Rize.
In this research, it was aimed to determine the perception of the local people residing in Rize towards the positive effects on the development of heliski tourism and the effect of these perceptions on the support they give to the development of heliski tourism. The research was structured by the quantitative research method, which is one of the three main approaches of methodology. The theoretical background of the research is based on the theory of social change. The research data were obtained by taking the opinions of the local people residing in Rize through the survey technique, using the convenience sampling method. Incorrect and incomplete questionnaires were removed and 400 questionnaires were analyzed. According to the results of the research, there is a high level, positive and significant difference between the socio-cultural positive effects and economic positive effects of heliski tourism and the support given to the development of heliski tourism, while there is a negative relationship between environmental positive effects and the support given to the development of heliski tourism. While the economical dimension was determined to be the most important among the economic, socio-cultural and environmental dimensions that affect the support given to heliski tourism, the environmental dimension was found to negatively affect the support of heliski tourism.

\section{GIiRIŞ}

"Turizmin etkisi" kavramı yaklaşık olarak 50 yıldan beridir akademisyenler arasında önemli derecede ilgi görmektedir (Brougham ve Butler, 1981; Akova, 2006; Vodeb vd., 2021). Literratür incelendiğinde, yerel halkın turizm algılarıyla ilgili önemli oranda bir çalışma hacmi olduğu anlaşılmaktadır (Brougham ve Butler, 1981; Ap, 1997; Andereck vd., 2005; Diedrich ve Garc1'a-Buades, 2009; Türkmen vd., 2018; Ayaz ve Parlak, 2019; Vodeb vd., 2021). Çalışmalarda, turizmin yerel halk üzerindeki etkileri ve yerel halkın turizme karşı algı ve tutumları, bir dizi faktörle incelenmiştir. Buna bağlı olarak, çalışmalar genellikle yerel halkın tutum ve algısı üzerinde yoğunlaşmıştır.

Turizmin gelişme gösterdiği bir bölgede turizm faaliyetleri üç boyutta etki yaratmaktadır. Bunlar; ekonomik, sosyo-kültürel ve çevresel etkiler olarak sıralanmaktadır (Avcıkurt, 2007: 121-122). Bu üç boyut yerel halk özelinde hem olumlu hem de olumsuz sonuçlar doğurabilmektedir. Dahası, sıralanan etkilerin yerel halkın turizme karşı algısını ortaya çıkartabilecek etki gücüne sahip boyutlar olduğu ileri sürülmektedir (Çolak ve Tayfun, 2017: 582). Cengiz ve Kırkbir'in (2007) yapmış olduğu araştırmada, sosyal değişism teorsi şemsiyesi altında, yerel halkın turizm sonucu istenmeyen ve kabullenilmeyecek maliyetlerin olmayacagına inandıkları takdirde turistlerle karşılıklı iletişimde bulunabilecekleri belirtilmektedir. Bu noktadan hareketle, yerel halka turizmin olumlu taraflarının olumsuz taraflarından fazla olduğu gösterilmeli ve yerel halkın turizmin planlanması sürecine aktif olarak dahil edilmesi sağlanmalıdır. Çünkü, yerel halkın olumlu yönde turizm algısı bu eylemler doğrultusunda geliştirilecektir. Böylelikle yerel halkın turizme desteği sağlanmış olacaktır. Yerel halkın turizmi desteklemesi gelecek dönemlerde yerel düzeyde turizm politikalarına, pazarlamasına ve programların düzenlenmesine büyük oranda kolaylık sağlayacaktır (Türkiye'de devlet planlamasının başladığı 1963 yılından bu yana turizm, ülkenin ekonomik kalkınmasında önemli bir sektör olarak kabul edilmektedir. Bu dönemden itibaren gelen hükümetler turizmin gelişmesi için yatırımları teşvik etmek ve turizm potansiyeli yüksek 
alanlara yönlendirmek için çok sayıda girişim başlatmıştır (Korça, 1998: 195). Bu girişimler neticesinde özellikle Marmara, Ege ve Akdeniz'in dar kıyı şeritlerinde turizm tesislerinin yoğunlaştı̆̆ 1 ve dolayısıyla turizm faaliyetlerinin bu bölgelerde arttığ1 söylenebilir. Bu sebeple, bu bölgelerin ekonomisinde turizm faaliyetleri etkin rol almaya başlamıştır. Diğer bölgeler de ise uzun bir dönem genellikle tarıma dayalı bir kalkınma modeli uygulandığı söylenebilir. Yirmi birinci yüzyılla beraber dünyada değişim ve dönüşüm rüzgârları esmeye başlamış ve Türkiye de bu değişim ve dönüşüm rüzgârından payına düşeni almıştır. Özellikle, son yıllarda Türkiye'deki birçok kırsal alanın ve küçük toplulukların ekonomik tabanında büyük bir değişim yaşanmıştır. Bir zamanlar tarımla uğraşan ve ekonomilerini tarımsal üretimle kalkındırmaya çalışan toplumların çoğunun alternatif yeni yollar arayışı içine girdiği (A. Lepp, 2007: 877878) ve turizm sektörüne yöneldiği bilinmektedir. $\mathrm{Bu}$ alternatif kalkınma arayışı tarım sektörünün önem kaybetmesine (Akkaşoğlu Akyol Ulama Zengin, 2019: 1194) turizm sektörünün ise, özellikle küreselleşme ve teknolojik gelişmeler sayesinde kırsal bölgelerde önem kazanmasına neden olmuştur. Özetle, kırsal bölgeler 2000'li yıllarla beraber turizm sektörüne hızla entegre olmaya başlamıştır.

Türkiye özelinde bakıldığı zaman, kırsal alanlarının sahip olduğu doğal güzellikleri ile ön plana çıkan iller arasında ilk göze çarpan Rize ilidir. Rize sadece kırsal alanları ile değil, aynı zamanda Kaçkar Dağları'nın eteklerinde yer alan yüksek rakımlı doğal güzelliklere, alabildiğince yeşil alana sahip yaylaları ile de bilinmektedir. Rize'nin sahip olduğu bu özellikler, onun Türkiye turizminde aktif rol almasını sağlamıştır (Erkılıç, 2019: 68). Rize, Doğu Karadeniz Bölgesi'nde bulunan, etrafi Trabzon, Erzurum, Bayburt, Artvin ve Karadeniz ile çevrili olan, $3920 \mathrm{~km}^{2}$ 'lik yüz ölçümüne, engebeli alanlara ve dağlık arazilere sahip bir ildir (Rize İl Kültür ve Turizm Müdürlüğü: 2019). Rize ili için en önemli ekonomik geçim kaynağ1 çay tarımıdır. Fakat son dönemlerde teknolojik ilerlemenin ve sosyal medya araçlarının gelişmesi ile Rize'nin karakteristik yapısı tanınır hale gelmiştir. Bu sayede Rize'de turizm faaliyetleri de hız kazanmaya başlamıştır. Yayla turizmi ve heliski (dağ dayağı) turizmi aktiviteleri Rize özelinde son dönemlerde ön plana çıkan alternatif turizm faaliyetleri olarak bilinmektedir. Özellikle, son yıllarda heliski turizmi önemli bir gelişme göstererek Rize ilinde turizmin hızla büyüyen segmentlerinden biri olmuştur. Dünyanın en adrenalin dolu aktivitelerinden biri olarak lanse edilen heliski; kayakçıları, helikopter ile yüksek dağların doruklarına bırakıp, aşağılara doğru kaymalarını sağlayan bir spor türüdür. Bu heyecan dolu spor aktivitesi Türkiye'de ilk kez 2003 yılından itibaren özellikle; İsviçre, Fransa, Almanya, İtalya, Avusturya, İngiltere, İspanya, Rusya, İsveç, Norveç, Finlandiya ve ABD gibi ülkelerden gelen heliski ve adrenalin tutkunu turistlerin talepleri üzerine Kaçkar Dağları'nda yapılmaya başlanmıştır (Zaman ve Birinci, 2009: 34).

Heliski turizmi hem ülke genelinde hem de Karadeniz Bölgesi'nde 2000'lı yılların başlarına kadar pek fazla tanınırlığa sahip bir spor türü değildi. Fakat, 2003 yılından itibaren heliski sporunun, Rize ili sınırları içerisinde yer alan ve heliski sporu için elverişli ortama sahip olan Kaçkar Dağları'nda yapılmaya başlanması ile ülke genelinde ve Karadeniz Bölgesi'nde bilinirliği artmıştır. Heliski sporunun Rize ilinde yapılmaya başlanması ile birlikte yerel halkın bu spora yönelik algı ve desteğinin hangi düzeyde olduğu merak edilen konular arasında yer almaya başlamıştır. Bu çalışma, hem literatürde sıkça karşılaşılan tutum araştırmalarının ötesine geçmeyi hem de turizmin yerel halkın yaşam kalitesi üzerindeki etkisinden ziyade alternatif bir turizm türü olan heliski turizminin yerel halk üzerinde yaratmış olduğu algıyı ve yerel halkın heliski turizmine desteğini açıklamaya çalışmaktadır (Karakaş ve Şengün, 2017: 186). 


\section{LITERATÜR TARAMASI}

Literatür incelendiğinde, yerel halkın turizm gelişimi açısından algı, tutum ve desteğini ölçmeyi amaçlayan birçok araştırmanın olduğu görülmektedir. $\mathrm{Bu}$ araştırmaların genelinde, araştırmacılar sadece turizmin gelişme gösterdiği destinasyonlarda belirgin olarak ortaya çıkan olumlu ya da olumsuz etkileri değil, aynı zamanda destinasyonun kimyasını değiştirebilecek ekonomik, çevresel ve sosyo-kültürel etkileri de incelemiştir.

Alaeddinoğlu (2007), Cengiz ve Kırkbir (2007), Doğan ve Üngüren (2012), Eshliki ve Kaboudi (2012), Solmaz (2014), Işı ve Çalkın (2016), Deniz (2016), Boğan ve Sarış̧1k (2016), Ayazlar ve Ayazlar (2016), Oğuzbalaban (2017), Karakaş ve Şengün (2017), Yıldız ve Çalışkan (2018), Erkılıç (2019), Ercan (2019) çalışmalarında; yerel halkın turizme yönelik algı ve tutumlarının büyük oranda olumlu yönde olduğu sonucuna ulaştıkları görülürken, Alaeddinoğlu (2008) ile Çolak ve Tayfun (2017) çalışmalarında; turizmden yeterli ekonomik desteğin sağlanamadığı ve devletin daha fazla yatırım ve denetim desteği sunması gerektiği sonucuna ulaşılmıştır. Teye ve arkadaşları (2002) ile Kervankıran ve Bulut (2015) çalışmalarında; yerel halkın turizme yönelik algı ve tutumlarının olumsuz yönde olduğu anlaşılmıştır. Çelikkanat ve Güçer (2014), Turker vd., (2016), Yıldız ve Polat (2016), Keskin ve Çontu (2011), Türkmen ve arkadaşları (2018), Ayaz ve Parlak (2019) çalışmalarında; yerel halkın turizme yönelik tutularında sadece olumlu yönde değil, aynı zamanda olumsuz yönde de bir eğilime sahip oldukları ifade edilmiştir.

Literatür incelendiğinde, yerel halkın turizme yönelik tutumlarında meydana gelen olumlu gelişmeleri teşvik eden unsurlardan birinin turizimden elde edilen ekonomik fayda olduğu sonucuna ulaşılmıştır (Ap, 1992; Jrowski vd., 1997; Weaver ve Lawton, 2001; García vd., 2015). Buradan, turizmin yerel toplumlar için önemli bir gelir kapısı olarak görüldüğü ve yörenin kalkınmasında etkili olduğu anlaşılabilir. Bunun yanında Brunt ve Courtney (1999)'un yapmış olduğu çalışmada, yerel halkın alışkanlıklarını, geleneklerini, sosyal yaşamını, inançlarını ve değerlerini etkileme gücüne sahip bir aktivite olarak turizmin sosyokültürel etkilerinin olumsuz yönde algılandığı görülmüştür. Bu durumun nedeni olarak da yerel halkın hayatının farklı anlarında, kültürel kimliklerini ve sosyal gerçekliklerini tehdit eden unsurların olması gösterilmiştir (García vd., 2015: 35). Literatür incelendiğinde ortaya cıkan diğer bir sonuç ise, yerel halkın turizme yönelik algısını etkileyen çevresel etkilerin varlığıdır. Literatürde yerel halkın turizmin çevresel etkilerini algılaması ve desteklemesi konusunda ikilik yaşadığı anlaşılmaktadır. Başka bir ifadeyle, yerel halkın turizmin çevresel etkileri konusunda hem olumlu hem de olumsuz algıya sahip oldukları görülmektedir (Liu ve Var, 1986; Yoon vd., 2001; García vd., 2015). Aynı zamanda bazı çalışmalarda, yerel halk turizmin doğal kaynakların korunması bağlamında desteklenmesi gerektiği ifade edilmektedir (Akis Peristianis Warner 1996; Andereck ve Nyaupane 2011). Bu durumun aksine, bazı çalışmalarda da turizm aktivitelerinin çevresel kirliliğe yol açtığı ve bu sebeple de yerel halk tarafindan desteklenmediği tespit edilmiştir (Perdue vd., 1987; Johnson Snepenger Akıs 1994; Brunt ve Courtney, 1999; Yoon vd., 2001; Andereck Valentine Knopf Vogt 2005). Bütün bunlar bir araya getirildiği zaman toplumların, turizmin olumlu ve olumsuz yönlerini kendi içinde ayırt etme gücüne ve böylece sektörün geliştiği bağlama göre değerlendirme yeteneğine de sahip oldukları düşünülebilir.

Önemli miktarda araştırmanın birincil amacının, sonuçların genelleştirilmesine yardımcı olan modellerin veya teorilerin aranması olsa da, literatür incelemesi aracılığıyla, elde edilen 
verilerin tutarlılık sağlamadığ 1 ve bu nedenle de tüm turistik yerler için geçerli olmadığ ileri sürülebilir.

Aynı zaman da yapılan incelemeler sonucunda turizm faaliyetlerinin yerel halk üzerinde farklı düzeylerde etki yarattığı da anlaşılmıştır (Akova, 2006: 9). Yukarıda yer alan çalışmaların genelinde bu çalışmaların araştırmanın yapıldığ 1 destinasyona özgü sonuçlar doğurduğu ve destinasyonda yaşayan yerel halkın demografik özelliklerine göre değişkenlik gösterdiği söylenebilir.

\section{METODOLOJI}

Araştırma yöntembilimin üç ana yaklaşımı içerisinde yer alan nicel araştırma yöntemi ile yapılandırılmıştır. Araştırmanın modeli ise, tarama modelleri içerisinde yer alan ilişkisel tarama modelinde desenlenmiştir. Araştırmada cinsiyet, yaş, doğum yeri, eğitim seviyesi, yaşam süresi, meslek, turistlerle etkileşim değişkenleri kullanılarak Rize ilinde ikamet eden yerel halkın heliski turizminin gelişim sürecindeki etkilerine yönelik algısı belirlenmeye çalışılmış ve araştırmanın hipotezleri bu veriler paralelinde oluşturulmuştur (García vd., 2015: 34).

Araştırmanın Modeli Şekil 1.’de gösterilmektedir.

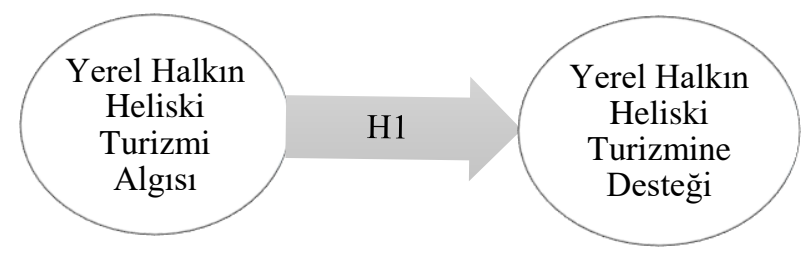

Şekil 1: Araştırmanın Modeli

Bir bölgede turizmin gelişmesi bağlı olarak bölgedeki yerel halk üzerinde, ekonomik, çevresel ve sosyo-kültürel açıdan hem olumlu hem de olumsuz etkilerden söz edilebilir. Çünkü turizmin gelişme gösterdiği bir bölgede ekonomik, çevresel ve sosyo-kültürel değişmelerin olması beklenen bir durumdur. Oluşacak bu değişimler, bölgede turizm alanında oluşacak toplam değişimleri meydana getirecektir. Turizmde oluşan toplam değişim ve toplam değişimi meydana getiren unsurlar, yerel halkın turizme karşı algılarını şekillendirip sektöre olan desteğinin olumlu ya da olumsuz olmasına sebep olacaktır (Yoon vd., 2001: 363-364). Bu çerçevede turizmin planlı bir şekilde ilerleme gösterip olumlu sonuçlar doğurması adına, yerel halkın katılımının planlama aşamasında sağlanması gerektiği ifade edilmiştir (Çalışkan ve Tütüncü, 2008: 28).

Yerel halkın turizm algısını ölçmeye çalışan bazı araştırmacılar sosyal değişim teorisinden (SDT) yararlanmışlardır (Jrowskı vd., 1997; Ap, 1997). En belirgin sosyolojik olaylardan biri olan fayda kavramı karşılıklı ilişkilerde SDT'nin beklediği en mükemmel sonuçtur. Başka bir deyişle, SDT karşılıklı ilişkilerde bireylerin çeşitli düzeylerde ortak fayda beklediği bir teoridir (Lyons ve Scott, 2012: 68). Perdue ve arkadaşları (1990) tarafindan SDT'nin yerel halkın turizm etkileri hakkındaki algılarını açıklamak için uygun bir çerçeve oluşturulduğu ifade edilmektedir. Sosyal değişim teorisi; "yerel halkın turizm gelişimine olan desteğinin, turizme yönelik algıladıkları faydanın, turizmin neden olduğu maliyeti geçmediği sürece devam ettiğini” belirtmektedir (Allen, 1994; Ap, 1992; Getz, 1994). Başka bir ifadeyle, turizmin sonuçlarını kişisel olarak değerli gören ve maliyetlerin faydaları aşmadığına inanan yerel halk, 
değişimin lehine olacak ve turizmin gelişmesini destekleyecektir (Jrowskı ve vd., 1997: 3). Sosyal değişim teorisi, turizmin algılanan etkisini şekillendiren ekonomik kazanç, turizm kaynaklarını kullanma, yaşama süresi ve çevreye karşı davranışları etkileyen faktörler arasındaki ilişkiyi açıklamak içinde kullanılmaktadır (Akova, 2006: 79). Kısaca, sosyal değişim teorisi, "bireyler ve gruplar arasında somut veya sembolik her türlü kaynak alışverişini anlamak için kavramsal bir temel sağlayan” bir teoridir (Andereck ve Vogt, 2000: 29).

$\mathrm{Bu}$ çerçevede, bu açıklamalardan yola çıkarak H1 hipotezi geliştirilmiştir.

H1: Yerel halkın heliski turizmi algısı ve heliski turizmini destekleme durumu arasında anlamlı ve pozitif yönlü bir ilişki vardır.

H1a: Yerel halkın heliski turizminin sosyo kültürel etkilerine yönelik algısı ve heliski turizmini destekleme durumu arasında anlamlı ve pozitif yönlü bir ilişki vardır.

H1b: Yerel halkın heliski turizminin çevresel etkilerine yönelik algısı ve heliski turizmini destekleme durumu arasında anlamlı ve pozitif yönlü bir ilişki vardır.

H1c: Yerel halkın heliski turizminin ekonomik etkilerine yönelik algısı ve heliski turizmini destekleme durumu arasında anlamlı ve pozitif yönlü bir ilişki vardır.

Araştırmanın evreni Rize ilinde ikamet eden yerel halk olarak belirlenmiştir. Araştırma evreninin Rize ili olarak seçilmesine, heliski turizminin Türkiye'de ilk olarak Rize ilinde faaliyet göstermeye başlaması sebep olmuştur. TUİK (2021), verilerine göre Rize'nin nüfusu 344.359 kişidir. Araştırmada, evrenin genişliğinden dolayı örneklem alma yoluna gidilmiştir. Mevcut araştırmada, sosyal bilimler alanında kullanılan bir örneklem türü olan gelişigüzel (kolayda) örnekleme yöntemi tercih edilmiş olup; nicel araştırmalarda kullanılmak üzere Karasar (2005) tarafından hazırlanan örnekleme hacmi hesaplama formülünden yararlanılmıştır. Evren hacminin kestirilebildiği durumlarda örneklem hacminin belirlenebilmesi için;

$\mathrm{n}=\frac{\mathrm{NZ}_{\alpha / 2}^{2} \sigma^{2}}{\mathrm{~d}^{2}(\mathrm{~N}-1)+\mathrm{Z}_{\alpha / 2}^{2} \sigma^{2}}$

formülü uygulanmaktadır.

Mevcut formüle göre; $\mathrm{N}$ : Anakütle hacmini, $\mathrm{d}^{2}: \pm$ yüzde sapmayı, $\mathrm{Z}_{\alpha / 2}$ : Sabit değeri ve $\sigma^{2}$ : Anakütle varyansına denk düşmektedir (Gazeloğlu ve Erkılıç, 2020: 65-66). Belirtilen formüle 1şığında çalışmada kullanılması gereken örneklem hacminin \%95 güven düzeyi ile en az;

$\frac{344.359 *(1,96)^{2} *(0,5)^{2}}{(0,05)^{2} *(344.359-1)+(1,96)^{2} *(0,5)^{2}}=384$

olması gerekmektedir. Araştırmaya başlamadan önce Recep Tayyip Erdoğan Üniversitesi Sosyal ve Beşeri Bilimler Etik Kurulu'ndan 30/03/2021 tarih ve 2021/85 sayı ile Recep Tayyip Erdoğan Üniversitesi Rektörlüğü'nden izin alınmıştır. Bundan sonraki süreçte analizler için yerel halka toplam 410 anket uygulanmış, eksik ve hatalı olan anketler elendikten sonra 400 anket değerlendirmeye alınmıştır. Aynı zamanda araştırma bulguları sadece araştırma kapsamındaki yerel halk için geçerli olup genellenemez.

Yazın taraması yapıldıktan sonra araştırma için en uygun ölçüm aracının Güneş’in (2014) çalışmasında geliştirmiş olduğu ölçek olduğuna karar verilmiştir. Araştırmada kullanılan ölçek, 
heliski turizminin algılanan sosyo-kültürel, ekonomik, çevresel pozitif etkilerini, heliski turizminin algılanan sosyo-kültürel, ekonomik, çevresel negatif etkilerini ve heliski turizminin gelişimine verilen desteği ölçmeye yönelik ifadelerden oluşmaktadır (Güneş, 2014).

Mevcut ölçek iki bölümden meydana gelmektedir. Ölçeğin birinci bölümü katılımcıların demografik özelliklerine yönelik on bir ifade yer alırken, ölçeğin ikinci bölümünde ise, yerel halkın heliski turizminin gelişimine yönelik algısını ve heliski turizminin gelişimine yönelik desteğini ölçen sorular (25 ifade) yer almaktadır.

Bu soruların değerlendirilmesinde 5'li likert (1 kesinlikle katılmıyorum, 2 katılmıyorum, 3 orta düzeyde katılıorum, 4 katılıyorum, 5 kesinlikle katılıyorum) tipi derecelendirme kullanılmıştır.

Araştırmanın geçerliliğini test etmek, faktörlerin çıkarılmasından önce, yanıtlanan verilerin faktör analizine uygunluğunu değerlendirmek için çeşitli testler kullanılmaktadır. Bu testler arasında Kaiser-Meyer-Olkin (KMO) Örnekleme Yeterliliği Ölçüsü ve Bartlett'in Küresellik Testi yer almaktadır. KMO indeksi 0 ile 1 arasında değişmekte olup, 0,50 değeri faktör analizi için uygun kabul edilmektedir (Albayrak, 2019: 130). Verilerin Faktör analizinin uygun olması için Bartlett'in Küresellik Testinin anlamlı olması gerekmektedir. Eğer veriler 0,05'ten küçükse, bu verilerin faktör analizi için uygun olduğu söylenebilir (Williams Onsman Brown, 2010: 5).

Tablo 1'de mevcut çalışmada yapılan analizler sonucu KMO değerinin 0,920 olduğunun, Bartlett testinin değerinin ise, 0,05 değerinden küçük olduğunun tespit edildiği gösterilmektedir.

Tablo 1: Yerel Halkın Heliski Turizmine Yönelik Algısı Ölçeğinin Kaiser Meyer-Olkin (KMO) ve Bartlett Testi

\begin{tabular}{|l|l|}
\hline KMO & 0,920 \\
\hline Bartlett's Test of Sphericity & $\mathrm{X}^{2}: 8860,03 ;$ Sig:0,00 \\
\hline
\end{tabular}

Araştırmanın yapıldı ğı konu çerçevesinde araştırmaya katılan kişilerin vermiş olduğu cevaplara göre ifadeler arasında var olan korelasyonu hesaplayıp, birbiri ile ilişkili olan ifadelerin gruplandırılması işlemine faktör analizi denir (Ural ve Kılıç, 2018: 263). Daha kısa bir ifadeyle faktör analizi, çok sayıda birbiriyle ilişkili değişkenleri gruplandırarak, daha az sayıda anlamlı yeni değişkenler keşfetmek amacıyla yapılan analizlere denir (Büyüköztürk, 2002: 472).

Yapılan keşfedici faktör analizinde "Heliski Turizmine Yönelik Yerel Halkın Algısı” ölçeği ve "Yerel Halkın Heliski Turizmine Desteği" ölçeği farklı tablo içerisinde değerlendirilmiştir. Keşfedici faktör analizi yapılarak faktör yapısı ortaya çıkartılmış ve tüm ifadeler değerlendirilmiştir.

Tablo 2'de yapılan keşfedici faktör analizi sonucunda yerel halkın heliski turizmi algısı ölçeği içerisinde üç boyuta ulaşılmıştır. Bunlar; yerel halkın heliski turizmine yönelik ekonomik algısı (HEA), yerel halkın heliski turizmine yönelik sosyo-kültürel algısı (HSA) ve yerel halkın heliski turizmine yönelik çevresel algısı (HÇA) boyutları şeklinde sıralanmaktadır. 
Tablo 2: Yerel Halkın Heliski Turizmine Yönelik Algısı Ölçeğinin Keşfedici (Açımlayıcı) Faktör Analizi

\begin{tabular}{|c|c|c|c|}
\hline & HEA & HSA & HÇA \\
\hline $\begin{array}{l}\text { Heliski (Dağ Kayağı) turizmi alt yapı ve yatırımı artırarak bölgenin gelişimine katkıda } \\
\text { bulunur. }\end{array}$ & 0,90 & & \\
\hline Heliski (Dağ Kayağı) turizmi genel anlamda bölgenin gelirini arttırır. & 0,89 & & \\
\hline Heliski (Dağ Kayağı) turizmi iş bulma olanaklarını arttırır. & 0,89 & & \\
\hline $\begin{array}{l}\text { Heliski (Dağ Kayağı) turizmi bölgede yaşayanların yaşam standartlarına ve gelirine } \\
\text { katkıda bulunur }\end{array}$ & 0,88 & & \\
\hline Heliski (Dağ Kayağı) turizmi kültürel etkinliklerin çeşitliliğini arttırır. & 0,87 & & \\
\hline Heliski (Dağ Kayağı) turizminin daha fazla gelişimi için çaba sarf edilmelidir. & 0,83 & & \\
\hline Heliski (Dağ Kayağı) turizmi farklı kültürleri tanımayı sağlar. & 0,82 & & \\
\hline Heliski (Dağ Kayağı turizmi kültürel ve tarihi varlıklara olan talebi arttırır. & 0,82 & & \\
\hline Heliski (Dağ Kayağı) turizmi altyapıyı geliştirir (su, elektrik, telefon vb.). & 0,80 & & \\
\hline $\begin{array}{l}\text { Heliski (Dağ Kayağı) turizmi çevre korumasını sağlayarak bölge imajına katkıda } \\
\text { bulunur }\end{array}$ & 0,78 & & \\
\hline $\begin{array}{l}\text { Heliski (Dağ Kayağı) turizmi kamu tesislerini geliştirir (kaldırım, trafik ağı ve şehir } \\
\text { merkezi vb.) }\end{array}$ & 0,76 & & \\
\hline Heliski (Dağ Kayağı) turizmi kumar gibi yasal olmayan oyunların artmasına neden olur. & & 0,90 & \\
\hline Heliski (Dağ Kayağı) turizmi yerel dilde bozulmalara neden olur. & & 0,85 & \\
\hline Heliski (Dağ Kayağı) turizmi bölgedeki suç oranının artmasına neden olur. & & 0,81 & \\
\hline Heliski (Dağ Kayağı) turizmi alkol tüketimi gibi olayların artmasına neden olur. & & 0,80 & \\
\hline Heliski (Dağ Kayağı) turizmi trafik kazalarının artmasına neden olur. & & 0,77 & \\
\hline Heliski (Dağ Kayağı) turizmi hayat pahalılığına neden olur. & & 0,40 & \\
\hline Heliski (Dağ Kayağı) turizmi doğal çevreye zarar verir. & & & 0,95 \\
\hline Heliski (Dağ Kayağı) turizmi yerel eko sistemi tahrip eder. & & & 0,89 \\
\hline $\begin{array}{l}\text { Heliski (Dağ Kayağı) turizmi çevrenin kirlenmesine neden olur (çöp, su, hava, gürültü } \\
\text { kirliliği vb.). }\end{array}$ & & & 0,88 \\
\hline Açıklanan Toplam Varyans & \multicolumn{2}{|c|}{$\% 70,98$} & \\
\hline Cronbach's Alpha & 0,87 & 0,76 & 0,69 \\
\hline
\end{tabular}

Tablo 3'teki heliski turizmi ölçeğinin analiz sonuçları incelendiğinde; KMO testinin değeri 0,862 , Bartlett testinin sonucu ise 0,000 çıkmıştır. Bu veriler doğrultusunda verilerin faktör analizine uygun olduğu sonucuna varılmıştır.

Tablo 3: Heliski Turizmi Destek Ölçeğinin Kaiser- Meyer- Olkin (KMO)ve Bartlett Testi

\begin{tabular}{|l|l|}
\hline KMO & 0,862 \\
\hline Bartlett's Test of Sphericity & $X^{2}: 2496,95 ;$ Sig: 0,00 \\
\hline
\end{tabular}

Tablo 4'de "Heliski Turizmi Destek” (DÖ) ölçeği için keşfedici faktör analizi yapılmıştır. Keşfedici faktör analizi yapılarak faktör yapısı ortaya çıkartılmış ve tüm ifadeler incelenmiştir. Yapılan analiz sonucunda ölçek içerisinde yer alan 4 ifade tek boyut oluşturmuştur.

Tablo 4: Heliski Turizmi Desteği Ölçeğinin Keşfedici (Açımlayıcı) Faktör Analizi

\begin{tabular}{|l|l|}
\hline & DÖ \\
\hline Heliski (Dağ Kayağı) turizmi gelişimini destekliyorum. & 0,97 \\
\hline Heliski (Dağ Kayağı) turizmi yatırımları artarak devam etmelidir. & 0,97 \\
\hline $\begin{array}{l}\text { Heliski (Dağ Kayağı) turizmi toplumumuzun bir parçası olmaya } \\
\text { devam etmelidir. }\end{array}$ & 0,96 \\
\hline
\end{tabular}




\begin{tabular}{|l|l|}
\hline $\begin{array}{l}\text { Heliski (Dağ Kayağı) turizminin daha fazla gelişimi için çaba sarf } \\
\text { edilmelidir. }\end{array}$ & 0,94 \\
\hline Açıklanan Toplam Varyans & $\% 93,23$ \\
\hline Cronbach's Alpha & 0,97 \\
\hline
\end{tabular}

Araştırmada kullanılan ölçeğin güvenirlik analizi için Cronbach's Alpha değerleri hesaplanmıştır. Cronbach's Alpha, ölçekte bulunan soruların birbirleriyle olan uyumunu ölçmeye yarayan bir iç tutarlılık ölçütüdür. Özellikle likert tipli ölçeklerde kullanılması uygun bir iç tutarlılık analizidir (Ercan ve Kan, 2004: 213). Cronbach's Alpha değeri 0 ile 1 arasında bir değer almaktadır ve kullanılan ölçeğin Cronbach's Alpha değeri $0,60<\alpha<0,80$ aralığında olduğunda ölçek oldukça güvenilir sayılırken $0,80<\alpha<1$ aralığında yüksek güvenilir sayılmaktadır (Yıldız ve Uzunsakal, 2018: 19).

\section{BULGULAR}

Tablo 5 incelendiğinde katılımcıların \%51,1'i kadın katılımcılardan oluştuğu tespit edilmiştir. Katılımcıların yaş aralıkları incelendiğinde $21-30$ yaş arası \%30,8 ve 31-40 yaş arası \%36,6 ile toplam katılımcıların yarısından fazlısını oluşturduğu görülmektedir. Katılımcıların eğitim düzeyleri ile ilgili verilere göre; lisans \%48,3 katılımcıların yarısına yakınını oluşturulduğu görülmektedir. Katılımcıların Rize ilinde ikamet sürelerini incelendiğinde; katılımcıların \%54,0’1 yirmi bir yıldan fazla süredir Rize'de ikamet ettiklerini belirtmişlerdir. Katılımcılar aylık gelir açısından incelendiğinde ise, katılımcıların \%22,5'luk kısmının geliri olmadığı ve buna karşılık olarak da \%39,8'lik bir kesimin 3001-6000 TL arasında gelire sahip oldukları tespit edilmiştir. Katılımcılar mesleki bağlamda değerlendirildiğinde \%11,3’ünün çalışmadığı, \%39,8'inin de memur olduğu görülmüştür.

Tablo 5: Katılımcıların Demografik Özelliklerine Göre Dağılımı (n=400)

\begin{tabular}{|c|c|c|c|c|c|c|c|}
\hline Değişkenler & Gruplar & (f) & $\%$ & Değișkenler & Gruplar & (f) & $\%$ \\
\hline \multirow{2}{*}{ Cinsiyet } & Kadın & 206 & 51,5 & \multirow{12}{*}{$\begin{array}{l}\text { İkamet } \\
\text { Edilen İlçe }\end{array}$} & Ardeșen & 165 & 41,3 \\
\hline & Erkek & 194 & 48,5 & & Pazar & 31 & 7,8 \\
\hline Medeni & Evli & 212 & 53,0 & & Findiklı & 31 & 7,8 \\
\hline Durum & Bekâr & 188 & 47,0 & & Çamlıhemşin & 32 & 8,0 \\
\hline \multirow[t]{4}{*}{ Yaş } & $0-20$ yaş & 23 & 5,8 & & Çayeli & 22 & 5,5 \\
\hline & $21-30$ yaş & 123 & 30,8 & & Derepazar1 & 1 & ,3 \\
\hline & $31-40$ yaş & 146 & 36,5 & & Güneysu & 8 & 2,0 \\
\hline & 41 yaş ve üzeri & 108 & 27,0 & & Hemşin & 1 & ,3 \\
\hline \multirow[t]{4}{*}{ Doğum Yeri } & Rize & 257 & 64,2 & & Kalkandere & 4 & 1,0 \\
\hline & Diğer & 143 & 35,8 & & İyidere & 3 & ,8 \\
\hline & & & & & İkizdere & 1 & ,3 \\
\hline & & & & & Rize İl Merkezi & 101 & 25,3 \\
\hline \multirow[t]{7}{*}{ Eğitim } & Okuryazar değil & 1 & 0,3 & \multirow{7}{*}{$\begin{array}{l}\text { Yaşam } \\
\text { Süresi }\end{array}$} & 1 y1ldan az & 31 & 7,8 \\
\hline & Okuryazar & 11 & 0,3 & & $1-5$ y1l & 39 & 9,8 \\
\hline & İlköğretim & 17 & 4,3 & & $6-10$ y1l & 36 & 9,0 \\
\hline & Lise & 63 & 15,8 & & $11-15$ y1l & 33 & 8,3 \\
\hline & Ön Lisans & 52 & 13,0 & & $16-20 \mathrm{y} 11$ & 45 & 11,3 \\
\hline & Lisans & 193 & 48,3 & & 21 yıl ve üzeri & 216 & 54,0 \\
\hline & Lisansüstü & 73 & 18,3 & & & & \\
\hline
\end{tabular}




\begin{tabular}{|c|c|c|c|c|c|c|c|}
\hline Meslek & $\begin{array}{l}\text { Çalışmıyor } \\
\text { Öğrenci } \\
\text { Memur } \\
\text { Özel Sektör } \\
\text { Çalışanı } \\
\text { Ev Hanımı } \\
\text { Esnaf } \\
\text { İş İnsanı } \\
\text { Emekli }\end{array}$ & $\begin{array}{l}45 \\
50 \\
159 \\
73 \\
15 \\
27 \\
24 \\
7\end{array}$ & $\begin{array}{l}11,3 \\
12,5 \\
39,8 \\
18,3 \\
3,8 \\
6,8 \\
6,0 \\
1,8\end{array}$ & Aylık Gelir & $\begin{array}{l}\text { Gelirim yok } \\
3000 \text { TL'den az } \\
3001-6000 \mathrm{TL} \\
6001-10,000 \mathrm{TL} \\
10,001 \text { TL ve } \\
\text { üzeri }\end{array}$ & $\begin{array}{l}90 \\
49 \\
159 \\
77 \\
25\end{array}$ & $\begin{array}{l}22,5 \\
12,3 \\
39,8 \\
19,3 \\
6,3\end{array}$ \\
\hline $\begin{array}{l}\text { Turistlerle } \\
\text { İletişim } \\
\text { Kuruyor } \\
\text { Musunuz? }\end{array}$ & $\begin{array}{l}\text { Evet } \\
\text { Hayır }\end{array}$ & $\begin{array}{l}116 \\
284\end{array}$ & $\begin{array}{l}29 \\
71\end{array}$ & \begin{tabular}{ll}
\multicolumn{2}{l}{ Yaptığınız } \\
İş & Turizm \\
ile & Ilgili \\
Mi? &
\end{tabular} & $\begin{array}{l}\text { Evet } \\
\text { Hayır }\end{array}$ & $\begin{array}{l}250 \\
150\end{array}$ & $\begin{array}{l}62,5 \\
37,5\end{array}$ \\
\hline
\end{tabular}

Yerli halkın heliski turizmine ilişkin görüşlerinin belirtildiği Tablo 6'da "heliski turizmi bölgede yaşayanların yaşam standartlarına ve gelirine katkıda bulunur" ( $\bar{x}=3,61)$, "heliski turizmi alt yapı ve yatırımı artırarak bölgenin gelişimine katkıda bulunur" $(\bar{x}=3,67)$, "heliski turizmi iş bulma olanaklarını arttırır" $(\overline{\mathrm{x}}=3,57)$, "heliski turizmi genel anlamda bölgenin gelirini arttırır" $(\overline{\mathrm{x}}=3,56)$, "heliski turizmi yatırımları artarak devam etmelidir" $(\overline{\mathrm{x}}=3,54)$, "heliski turizminin daha fazla gelişimi için çaba sarf edilmelidir" ( $\bar{x}=3,64)$, "heliski turizmi kültürel etkinliklerin çeşitliliğini arttırır" $(\overline{\mathrm{x}}=3,64)$, "heliski turizmi farklı kültürleri tanımayı sağlar" ( $\bar{x}=3,65)$, "heliski turizmi gelişimini destekliyorum" $(\bar{x}=3,64)$, "heliski turizmi toplumumuzun bir parçası olmaya devam etmelidir" $(\overline{\mathrm{x}}=3,56)$ ifadelerine katılımın yüksek olduğu tespit edilmiştir.

Tablo 6: Ölçek Maddelerine İlişkin Betimsel İstatistikler (n=400)

\begin{tabular}{|c|c|c|c|c|c|c|c|c|}
\hline & \multirow[t]{2}{*}{ İfadeler } & 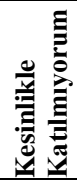 & 声 & 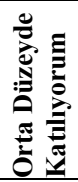 & E & 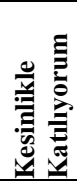 & $\overline{\mathbf{x}}$ & SS \\
\hline & & $\%$ & $\%$ & $\%$ & $\%$ & $\%$ & & \\
\hline \multirow{7}{*}{ 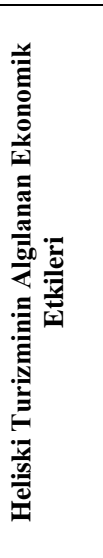 } & $\begin{array}{l}\text { Heliski (Dağ Kayağı) turizmi bölgede } \\
\text { yaşayanların yaşam standartlarına ve } \\
\text { gelirine katkıda bulunur. }\end{array}$ & 12,0 & 10,5 & 17,8 & 31,0 & 28,5 & 3,61 & 1,98 \\
\hline & $\begin{array}{l}\text { Heliski (Dağ Kayağı) turizmi alt yapı ve } \\
\text { yatırımı artırarak bölgenin gelişimine } \\
\text { katkıda bulunur. }\end{array}$ & 10,5 & 9,0 & 13,0 & 37,3 & 30,3 & 3,67 & 1,27 \\
\hline & $\begin{array}{l}\text { Heliski (Dağ Kayağı) turizmi iş bulma } \\
\text { olanaklarını arttırır. }\end{array}$ & 10,0 & 14,0 & 17,3 & 31,3 & 27,5 & 3,52 & 1,29 \\
\hline & $\begin{array}{l}\text { Heliski (Dağ Kayağı) turizmi genel } \\
\text { anlamda bölgenin gelirini arttırır. }\end{array}$ & 9,5 & 10,8 & 15,5 & 34,0 & 30,3 & 3,4 & 1,27 \\
\hline & $\begin{array}{l}\text { Heliski (Dağ Kayağı) turizmi hayat } \\
\text { pahalılığına neden olur. }\end{array}$ & 20,3 & 33,3 & 23,0 & 16,3 & 7,0 & 2,4 & 1,92 \\
\hline & $\begin{array}{l}\text { Heliski (Dağ Kayağı) turizmi mal ve } \\
\text { hizmetlerin fiyatını artmasına neden olur. }\end{array}$ & 16,8 & 28,0 & 24,0 & 23,8 & 7,5 & 2,77 & 1,19 \\
\hline & $\begin{array}{l}\text { Heliski (Dağ Kayağı) turizmi emlak } \\
\text { fiyatlarının artmasına neden olur. }\end{array}$ & 19,0 & 19,8 & 25,5 & 22,8 & 13,0 & 2,91 & 1,30 \\
\hline 语䓀 & $\begin{array}{l}\text { Heliski (Dağ Kayağı turizmi kültürel ve } \\
\text { tarihi varlıklara olan talebi arttırır. }\end{array}$ & 11,3 & 15,3 & 16,0 & 34,3 & 23,3 & 3,43 & 1,30 \\
\hline 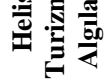 & $\begin{array}{l}\text { Heliski (Dağ Kayağı) turizmi kültürel } \\
\text { etkinliklerin çeşitliliğini arttırır. }\end{array}$ & 13,3 & 6,8 & 14,5 & 37,3 & 28,0 & 3,64 & 1,60 \\
\hline
\end{tabular}




\begin{tabular}{|c|c|c|c|c|c|c|c|c|}
\hline & $\begin{array}{l}\text { Heliski (Dağ Kayağı) } \\
\text { kültürleri tanımayı sağlar. }\end{array}$ & 10,5 & 10,3 & 14,2 & 33,8 & 31,3 & 3,65 & 1,30 \\
\hline & $\begin{array}{l}\text { Heliski (Dă̆ Kayağı) turizmi bölgedeki suç } \\
\text { oranının artmasına neden olur. }\end{array}$ & 46,3 & 31,8 & 12,8 & 5,8 & 3,5 & 1,88 & 1,06 \\
\hline & $\begin{array}{l}\text { Heliski (Dağ Kayağı turizmi alkol } \\
\text { tüketimi, fuhuş gibi olayların artmasına } \\
\text { neden olur. }\end{array}$ & 34,0 & 31,3 & 15,5 & 13,5 & 5,8 & 2,25 & 1,09 \\
\hline & $\begin{array}{l}\text { Heliski (Dağ Kayağı) turizmi yerel dilde } \\
\text { bozulmalara neden olur. }\end{array}$ & 40,5 & 33,5 & 14,8 & 7,2 & 4,0 & 2,00 & 1,09 \\
\hline & $\begin{array}{l}\text { Heliski (Dağ Kayağı) turizmi kumar gibi } \\
\text { yasal olmayan oyunların artmasına neden } \\
\text { olur. }\end{array}$ & 47,0 & 34,8 & 9,8 & 6,0 & 2,5 & 1,82 & 1,00 \\
\hline & $\begin{array}{l}\text { Heliski (Dağ Kayağı) turizmi trafik } \\
\text { kazalarının artmasına neden olur. }\end{array}$ & 37,0 & 33,3 & 17,5 & 8,5 & 3,8 & 2,08 & 1,10 \\
\hline & $\begin{array}{l}\text { Heliski (Dağ Kayağı) turizmi kamu } \\
\text { tesislerini geliştirir (kaldırım, trafik ağı ve } \\
\text { şehir merkezi vb.). }\end{array}$ & 13,5 & 13,5 & 17,8 & 29,5 & 25,8 & 3,40 & 1,35 \\
\hline & $\begin{array}{l}\text { Heliski (Dağ Kayağı) turizmi altyapıyı } \\
\text { gelistirir (su, elektrik, telefon vb.). }\end{array}$ & 11,3 & 17,3 & 17,3 & 30,3 & 23,8 & 3,42 & 1,61 \\
\hline \multirow{4}{*}{ 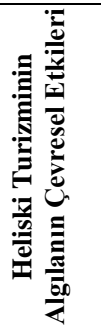 } & $\begin{array}{l}\text { Heliski (Dağ Kayağı) turizmi çevre } \\
\text { korumasını sağlayarak bölge imajına } \\
\text { katkıda bulunur }\end{array}$ & 12,3 & 16,3 & 18,8 & 30,3 & 22,5 & 3,34 & 1,31 \\
\hline & $\begin{array}{l}\text { Heliski (Dağ Kayağı) turizmi çevrenin } \\
\text { kirlenmesine neden olur (çöp, su, hava, } \\
\text { gürültü kirliliği vb.). }\end{array}$ & 23,8 & 30,0 & 22,8 & 13,3 & 10,3 & 2,56 & 1,26 \\
\hline & $\begin{array}{l}\text { Heliski (Dağ Kayağı) turizmi doğal çevreye } \\
\text { zarar verir. }\end{array}$ & 27,3 & 29,8 & 20,5 & 12,0 & 10,5 & 2,48 & 1,29 \\
\hline & $\begin{array}{l}\text { Heliski (Dağ Kayağı) turizmi yerel eko } \\
\text { sistemi tahrip eder. }\end{array}$ & 25,5 & 31,0 & 20,8 & 13,0 & 9,8 & 2,50 & 1,28 \\
\hline \multirow{4}{*}{ 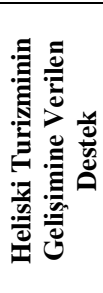 } & $\begin{array}{l}\text { Heliski (Dağ Kayağı) turizminin daha fazla } \\
\text { gelişimi için çaba sarf edilmelidir. }\end{array}$ & 22,0 & 9,8 & 17,8 & 31,3 & 29,3 & 3,56 & 1,32 \\
\hline & $\begin{array}{l}\text { Heliski (Dağ Kayağı) turizmi yatırımları } \\
\text { artarak devam etmelidir. }\end{array}$ & 12,5 & 9,3 & 18,8 & 30,0 & 29,5 & 3,54 & 1,33 \\
\hline & $\begin{array}{l}\text { Heliski (Dă̆ Kayağı) turizmi gelişimini } \\
\text { destekliyorum. }\end{array}$ & 12,3 & 8,0 & 16,0 & 30,5 & 33,3 & 3,64 & 1,33 \\
\hline & $\begin{array}{l}\text { Heliski (Dağ Kayağı } \text { turizmi } \\
\text { toplumumuzun bir parçası olmaya devam } \\
\text { etmelidir. }\end{array}$ & 12,0 & 8,8 & 20,0 & 29,3 & 30,0 & 3,56 & 1,32 \\
\hline
\end{tabular}

Heliski turizmine yönelik yerel halkın algısı ölçeğinin alt boyutları ile yerel halkın heliski turizmine yönelik heliski desteği ölçeğine beraber korelasyon analizi uygulanmıştır. Korelasyon katsayısı olarak Pearson korelasyon katsayısı kullanılmıştır.

Tablo 7'deki sonuçlara göre; heliski turizmine yönelik yerel halkın algısı ölçeğinin alt boyutlarından olan ekonomik boyut ile (EB) heliski algısı (HA) arasındaki korelasyon 0,900 olarak aralarında anlamlı ve pozitif bir ilişki bulunmaktadır. Heliski turizmine yönelik yerel halkın algısı ölçeğinin alt boyutlarından olan sosyo-kültürel boyut ile (SKB) heliski algısı (HA) arasındaki korelasyon 0,921 olarak aralarında anlamlı ve pozitif yönde bir ilişki bulunmaktadır. Yine heliski turizmine yönelik yerel halkın algısı ölçeğinin alt boyutlarından olan çevresel boyut (ÇB) ile heliski algısı (HA) arasındaki korelasyon 0,630 olarak aralarında anlamlı ve pozitif bir ilişki bulunmaktadır. Son olarak, heliski turizmine yönelik yerel halkın algısı (HA) ile yerel halkın heliski turizmine yönelik desteği (HD) arasındaki korelasyon 0,657 olarak aralarında anlamlı ve pozitif bir ilişki bulunmaktadır. 
Yerel halkın heliski turizmi ile heliski turizmi desteği arasındaki korelasyona göre; yerel halkın heliski turizmi algısının, yerel halkın heliski turizmine desteğini kazanmakta önemli olduğu sonucu ortaya çıkarılabilir.

Tablo 7: Heliski Turizmine Yönelik Yerel Halkın Algısı ve Desteğine İlişkin Korelasyon Analizi

\begin{tabular}{|l|l|l|l|l|l|}
\hline & EB & SKB & ÇB & HA & HD \\
\hline EB & 1 & $0,697^{* *}$ & $0,435^{* *}$ & $0,900^{* *}$ & $0,691^{* *}$ \\
\hline SKB & & 1 & $0,506^{* *}$ & $0,921^{* *}$ & $0,560^{* *}$ \\
\hline ÇB & & & 1 & $0,630^{* *}$ & $0,235^{* *}$ \\
\hline HA & & & & 1 & $0,657^{* *}$ \\
\hline HD & & & & & 1 \\
\hline
\end{tabular}

$* \mathrm{p}<0,05 * * \mathrm{p}<0,01$

Tablo 8'de yerel halkın heliski turizmi algısının heliski turizmi desteği üzerindeki etkisini belirlemek amacıyla basit doğrusal regresyon analizi gerçekleştirilmiştir. Değişkenler arasında anlamlı ve pozitif bir ilişki bulunmaktadır $(B=0,392)$ ve analiz sonuçları istatistiksel olarak anlamlidir $(\mathrm{p}<0,01)$.

Elde edilen bu sonuçlara göre "H1: "Yerel halkın heliski turizmi algısı ve heliski turizmini destekleme durumu arasında anlamlı ve pozitif yönlü bir ilişki vardır" hipotezi kabul edilmiştir.

Tablo 8: Yerel Halkın Heliski Turizmi Algısının Heliski Turizmi Desteği Üzerindeki Etkisine İlișkin Basit Doğrusal Regresyon Analizi

\begin{tabular}{|c|c|c|c|c|c|c|c|c|}
\hline \multirow[t]{2}{*}{ Değişkenler } & \multicolumn{2}{|c|}{$\begin{array}{c}\text { Standart } \\
\text { Olmayan } \\
\text { Katsayılar }\end{array}$} & \multirow{2}{*}{\begin{tabular}{|l}
$\begin{array}{c}\text { Standart } \\
\text { Katsaylar }\end{array}$ \\
$\beta$ \\
\end{tabular}} & \multirow[t]{2}{*}{$\mathbf{t}$} & \multirow[t]{2}{*}{ p } & \multirow[t]{2}{*}{$\mathbf{R R}^{2}$} & \multicolumn{2}{|c|}{ ANOVA } \\
\hline & B & S.E & & & & & $\mathbf{F}$ & $\mathbf{p}$ \\
\hline Sabit & ,392 & ,192 & & 2,046 & ,041 & 0,432 & 302,21 &, 000 \\
\hline $\begin{array}{l}\text { Heliski } \\
\text { AlgISI }\end{array}$ & 1,087 & ,063 & 657 & 17,384 &, 000 & & & \\
\hline $\mathrm{R}=0,657$ & Adj. R & 0,430 & & & & & & \\
\hline
\end{tabular}

Tablo 9'da bağımlı değişken (heliski turizmi desteği) ile bağımsız değişken (yerel halkın algısı) arasındaki ilişkilere yönelik hiyerarşik (sıralı) regresyon analizi yapılmış ve yerel halkın algısı değişkeninin alt boyutlarını oluşturan modelin anlamlı olduğu sonucuna ulaşılmıştır $(\mathrm{F}=133,292 ; \mathrm{p}<0,01)$. Hesaplanan $\mathrm{R}^{2}$ : 0,502 değeri ile modelin heliski desteği üzerindeki değişimlerin \%50,2 oranında yerel halkın algısı boyutları tarafından açıklandığı yapılan analiz sonucunda tespit edilmiştir. Pan ve Jackson (2008) ve Allison (1999), Varyans Enflasyon Faktör (VIF) değeri 2,5'in altında olduğunda analiz sonuçlarında doğrusallık probleminin bulunmadığını ileri sürmektedirler. Tolerans değeri 0,2 'den yüksek ve Durbin-Watson değeri de $0<\mathrm{DW}<4$ aralığında ( $\mathrm{DW}=2,079$ ) olduğu için model anlamlı olarak kabul edilmiştir.

Yerel halkın heliski turizmine yönelik algısının ekonomik, sosyo-kültürel ve çevresel $(* \mathrm{p}<0,01)$ boyutlarının heliski turizmi desteği üzerinde anlamlı etkilere sahip olduğu ortaya cıkmıştır. Yapılan analiz neticesinde yerel halkın heliski turizminin sosyo-kültürel etkilerine yönelik algısı, yerel halkın heliski turizmi desteğini olumlu yönde etkilemektedir. Ulaşılan bu sonuçlara göre; H1a: Yerel halkın heliski turizminin sosyo kültürel etkilerine yönelik algısı ve heliski turizmini destekleme durumu arasında anlamlı ve pozitif yönlü bir ilişki vardır" hipotezi kabul edilmiştir. Yerel halkın heliski turizminin çevresel etkilerine yönelik algısı, heliski turizmi desteğini olumsuz yönde etkilediği anlaşılmıştır. Bu bağlamda; H1b: "Yerel halkın 1768 
heliski turizminin çevresel etkilerine yönelik algısı ve heliski turizmini destekleme durumu arasında anlamlı ve pozitif yönlü bir ilişki vardır.” hipotezi reddedilmiştir. Son olarak, yerel halkın heliski turizminin ekonomik etkilerine yönelik algısı, heliski turizmi desteğini olumlu yönde etkilediği ortaya çıkmıştır. Bu sonuçlar ışığında; H1c: "Yerel halkın heliski turizminin ekonomik etkilerine yönelik algısı ve heliski turizmini destekleme durumu arasında anlamlı ve pozitif yönlü bir ilişki vardır." hipotezi kabul edilmiştir.

Tablo 9: Yerel Halkın Heliski Turizmi Algısı Ölçeğinin Alt Boyutlarının Yerel Halkın Heliski

Turizmi Desteği Ölçeği Üzerindeki Etkilerine İlişkin Hiyerarşik (Sıralı) Regresyon Analizi

\begin{tabular}{|c|c|c|c|c|c|c|c|c|}
\hline Değişkenleı & $\mathrm{B}$ & S.E. & $\beta$ & $\mathrm{t}$ & $\mathrm{p}$ & Tolerans & VIF & ANOVA \\
\hline Sabit & 0,792 & 0,15 & & 5,113 & 0,000 & & & \multirow{2}{*}{$\begin{array}{l}\text { F:364,131 } \\
\text { p:0,000 }\end{array}$} \\
\hline Ekonomik & 0,859 & 0,04 & 0,691 & 19,082 & 00,000 & 1,000 & 1,000 & \\
\hline & \multicolumn{2}{|c|}{ R: 0,691} & \multicolumn{3}{|c|}{$\mathrm{R}^{2}: 0,478$} & \multicolumn{3}{|c|}{ Adj. $R^{2}: 0,476$} \\
\hline Sabit & 0,521 & 0,177 & - & 2,940 & 0,003 & & & \multirow{3}{*}{$\begin{array}{l}\mathrm{F}: 190,495 \\
\mathrm{p}: 0,000\end{array}$} \\
\hline Ekonomik & 0,727 & 0,062 & 0,585 & 11,712 & 0,000 & 0,515 & 1,942 & \\
\hline $\begin{array}{l}\text { Sosyo- } \\
\text { Kültürel } \\
\end{array}$ & 0,253 & 0,083 & 0,152 & 3,047 & 0,002 & 0,515 & 1,942 & \\
\hline & \multicolumn{2}{|c|}{ R: 0,700} & \multicolumn{2}{|c|}{$\mathrm{R}^{2}: 0,490$} & \multicolumn{4}{|c|}{ Adj. $\mathrm{R}^{2}: 0,487$} \\
\hline Sabit & 0,685 & 0,183 & - & 3,751 & 0,000 & & & \multirow{4}{*}{$\begin{array}{l}\text { F: } 133,292 \\
\text { p: } 0,000\end{array}$} \\
\hline Ekonomik & 0,754 & 0,062 & 0,606 & 12,165 & 0,000 & 0,506 & 1,978 & \\
\hline $\begin{array}{l}\text { Sosyo- } \\
\text { Kültürel }\end{array}$ & 0,339 & 0,086 & 0,204 & 3,925 & 0,000 & 0,464 & 2,155 & \\
\hline Çevresel & $-0,180$ & 0,056 & $-0,132$ & $-3,182$ & 0,002 & 0,730 & 1,369 & \\
\hline \multicolumn{2}{|l|}{ R: 0,709} & \multicolumn{2}{|c|}{$\mathrm{R}^{2}: 0,502$} & \multicolumn{2}{|c|}{ Adj. $R^{2}: 0,499$} & \multicolumn{3}{|c|}{ Durbin-Watson: 2,079} \\
\hline
\end{tabular}

p $<0,01$ Sabit: Heliski Desteği (Bağımlı Değişken)

\section{SONUÇ VE ÖNERILER}

Araştırmada; literatürde yerel halkın turizm algısı ve turizmin gelişimine verilen destek konusu ile ilgili gerçekleştirilen birçok incelemenin alternatif turizm türlerinden biri olan heliski turizmi ile karşılaştırması yapılmıştır. Karşılaştırma sonucunda, literatürde yer alan yerel halkın turizm algısı ve turizmin gelişimine desteği üzerine yapılan incelemeler ile yerel halkın heliski turizm algısı ve yerel halkın heliski turizmi desteğine yönelik tutumlarını etkileyen ekonomik ve çevresel boyut açısından benzer sonuçlar, sosyokültürel boyut açısından farklı sonuçlar ortaya çıktığı görülmüştür. Bu nedenle, yerel halkın heliski turizmi konusundaki algısının ne yönde olduğu ve heliski turizmine yönelik desteğinin alg1 üzerinde nasıl bir etkiye sahip olduğu incelenerek, turizm paydaşlarının o yönde önlemler alması ve heliski turizmi konusunda literatürde mevcut çalışmanın ilk olması sebebi ile önemli katkılar sağlayacağı düşüncesi kabul edilmekte ve sonuçlar bu doğrultuda ortaya konmaktadır.

Araştırmada verilerin analizi sonucunda yerel halkın heliski turizminin gelişiminin sosyokültürel pozitif etkilerine katıldığı, yerel halkın heliski turizmi algısının negatif yönde etkilenmediği, kültürel değerlerin yok olmasına neden olmadığı, suç, uyuşturucu, kumar gibi sosyal problemlere neden olmadığını, turizmin kültürel aktiviteler konusunda ilerleme sağladığı, yerel halkın yaşam kalitesini arttırdığı, ekonomik kazanç sağladığ 1 , heliski turizminin yerel ekonomiyi desteklediğini, bölgeye daha fazla yatırımın yapılmasını sağladığı sonuçlarına ulaşılmıştır. 
Araştırma sonuçlarına göre heliski turizminin sosyo-kültürel pozitif ve ekonomik pozitif etkileri ile heliski turizmi gelişimine verilen destek arasında yüksek düzeyde, pozitif ve anlamlı; çevresel pozitif etkiler ile turizm gelişimine verilen destek arasında negatif bir ilişki olduğu görülmüştür. Heliski turizmine verilen desteği etkileyen ekonomik, sosyo-kültürel ve çevresel boyut arasından en önemli görülen ekonomik boyut olurken, heliski turizmi desteğini olumsuz yönde etkileyen unsurunda çevresel boyut olduğu belirlenmiştir.

Araştırma bulguları incelendiğinde yerel halkın turizm algıları ve turizme verdikleri destek konusunda Türkiye'de gerçekleştirilen birçok araştırma sonuçları ile ekonomik ve çevresel boyut açısından benzer sonuçlara, sosyokültürel bağlamda farklı sonuçlara ulaşılmıştır. Araştırmaların genelinde, yerel halkın turizme yönelik tutumlarında meydana gelen olumlu gelişmeleri teşvik eden unsurlardan birinin turizimden elde edilen ekonomik fayda olduğu sonucuna ulaşılmıştır (Ap, 1992; Jrowskı vd., 1997; Weaver ve Lawton, 2001; García dv., 2015). Buradan, turizmin yerel toplumlar için önemli bir gelir kapısı olarak görüldügü ve yörenin kalkınmasında etkili olduğu anlaşılmaktadır. Bunun yanında Brunt ve Courtney (1999)'un yapmış olduğu çalışmada, yerel halkın alışkanlıklarını, geleneklerini, sosyal yaşamını, inançlarını ve değerlerini etkileme gücüne sahip bir aktivite olarak turizmin sosyokültürel etkilerinin olumsuz yönde algılandığı görülmüştür. Bu durumun nedeni olarak da yerel halkın hayatının farklı anlarında, kültürel kimliklerini ve sosyal gerçekliklerini tehdit eden unsurların olması gösterilmiştir (García vd., 2015: 35). Literatürde yerel halkın turizmin çevresel etkilerini algılaması ve desteklemesi konusunda ikilik yaşadığı anlaşılmaktadır. Başka bir ifadeyle, yerel halkın turizmin çevresel etkileri konusunda hem olumlu hem de olumsuz algıya sahip oldukları görülmektedir (Liu ve Var, 1986; Yoon vd., 2001; García vd., 2015). Aynı zamanda bazı çalışmalarda, yerel halk turizmin doğal kaynakların korunması bağlamında desteklenmesi gerektiği ifade edilmektedir (Akis Peristianis Warner 1996; Andereck ve Nyaupane 2011). Bu durumun aksine, bazı çalışmalarda da turizm aktivitelerinin çevresel kirliliğe yol açtığı ve bu sebeple de yerel halk tarafından desteklenmediği tespit edilmiştir (Perdue vd., 1987; Johnson Snepenger Ak1s 1994; Brunt ve Courtney, 1999; Yoon vd., 2001; Andereck Valentine Knopf Vogt, 2005). Bütün bunlar bir araya getirildiği zaman toplumların, turizmin olumlu ve olumsuz yönlerini kendi içinde ayırt etme gücüne ve böylece sektörün geliştiği bağlama göre değerlendirme yeteneğine de sahip oldukları düşünülebilir.

Herşeyden önce heliski turizmi dünyanın çeşitli ülkelerinde yapılan yüksek adrenalinli bir alternatif turizm türü olduğu bilinmektedir. Özellikle Avrupa, İsviçre ve Kanada gibi dağ turizminin hakim olduğu ülkelerde faal olarak yapılmaktadır. Son yıllarda heliski turistleri Kaçkar Dağları'nın kar kalınlığının yüksek olması ve heliski turistlerin bir günde 10 ila 15 arasında kayma imkanına sahip olmaları nedenleri ile büyük ilgi göstermekte, büyüzden Kaçkar Dağları'nı tercih etmektedirler. Kaçkar Dağları'nın bu kendine özgü yapısı sayesinde heliski turistlerinin Kaçkar Dağları'nı tercih etmeleri bölge adına sosyo-ekonomik anlamda önemli getiriler sağlayacağı düşünülmektedir. Fakat bölge'de yerel halk, konaklama işletmeleri ve tur şirketleri nezdinde heliski turizmi farkındalığı oluşmamış gözükmektedir. Buna istinaden bölgede yapılan heliski turizmi aktivitelerine yerel halk, konaklama işletmeleri ve tur şirketleri daha çok iştirak etmelidir. Bu bağlamda, heliski turizminin, hem yüksek gelir grubuna hitap eden önemli bir alternatif turizm türü olduğu hem de Kaçkar Dağları'na heliski turistlerinin yoğun ilgi göstermesinden dolayı bölge paydaşlarının farkındalığı arttırılmalı, özellikle konaklama işletmelerinin ve tur şirketlerinin heliski turizmin gerektirmiş olduğu alt yapı sistemlerini bir an önce sağlamaları gerekmektedir. 
Bir destinasyonda nasıl ki turizmin yerel halk tarafından kabul edilmesi önemli ise benzer şekilde heliski turizmininde yerel halk tarafından kabul edilmesi önemlidir. Mevcut çalışma Rize ilinin ilçelerini içine alan bir araştırma evrenine sahiptir. Bu sebeple, gelecekte heliski turizmi üzerine çalışma yapmak isteyen araştırmacılar için Rize'nin heliski turizmi bağlamında ön plana cıkmış olan ilçesi olarak bilinen Çamlıhemşine özel bir araştırma yapmaları önerilmektedir. Ayrıca Rize ilindeki yerel halkın heliski turizmi ile ilgili olarak farkındalıkları da araştırılabilir.

\section{KAYNAKÇA}

ABAYHAN, Y. (2013). "Sosyal Etki Kuramı Bağlamında Psikolojik Dışlanma". Doktora Tezi, Hacettepe Üniversitesi, 2013.

AKIS, S., PERISTIANIS, N., \& WARNER, J. (1996). "Residents' Attitudes to Tourism Development: The Case of Cyprus". Tourism Management, 17(7): 481-494.

AKKAŞOĞLU, S., AKYOL, C., ULAMA, Ş., \& ZENGIN, B. (2019). "Tarım Turizmine Yönelik Hazırlanan Lisansüstü Tezlerin Bibliyometrik Analizi". Journal of Tourism and Gastronomy Studies, 7(2): 1193-1218.

AKOĞLAN KOZAK, M., EVREN, S., \& ÇAKIR, O. (2013). "Tarihsel Süreç İçinde Turizm Paradigması". Anatolia: Turizm Araştırmaları Dergisi, 24(1): 7-22.

AKOVA, O. (2006). "Yerel Halkın Turizmin Etkilerini Algılamalarına Ve Tutumlarına Yönelik Bir Araştırma". Akademik İncelemeler Dergisi, 1(2): 77-109.

ALAEDDINOĞLU, F. (2007). "Van Halkının Turisti ve Turizmi Algılama Şekli". Coğrafi Bilimler Dergisi, 5(1): 1-16.

ALAEDDINOĞLU, F. (2008). "Sivas Kentinde Halkın Turiste ve Turizme Bakışı". Uluslararası İnsan Bilimleri Dergisi, 5(2): 1-23.

ALBAYRAK, A. S. (2019). "SPSS Uygulamalı Çok Değişkenli İstatistik Teknikleri". Celepler Basım Yayım Dağıtım, Trabzon.

ALLEN, L. R. (1994). "Rural Residents Attidutes Toward Recreation and Tourism Development". Journal of Travel Research, 3(4): 27-33.

ALPAY, E. E., YAVUZ, M., \& KAHYAOĞLU, M. B. (2015). Gelir Durumunun Risk Algisına Etki Eden Diğer Sosyo-Ekonomik ve Demografik Faktörler Üzerindeki Etkisi". C.Ü. İktisadi ve İdari Bilimler Dergisi, 16(1): 205-226.

ALTINBAŞ, D. (2006). "Feminist Tartışmalarda Liberal Feminizm". Kadın Araştırmaları Dergisi, (9): 21-52.

ALTINTAŞ, V. "Turizmin Gelişiminin Yerel Halkın Yaşam Kalitesi Üzerine Etkileri: Alanya Bölge Örneği". Doktora Tezi, Akdeniz Üniversitesi, 2006.

ANDERECK, K. L., \& NYAUPANE, G. P. (2011). "Exploring The Nature of Tourism and Quality of Life Perceptions Among Residents". Journal of Travel Research, 50(3): 248-260. 
ANDERECK, K. L., \& VOGT, C. A. (2000). "The Relationship Between Residents' Attitudes Toward Tourism and Tourism Development Options". Journal of Travel Research, 39(1): 27-36.

ANDERECK, K. L., VALENTINE, K. M., KNOPF, R. C., \& VOGT, C. A. (2005). Residents' Perceptions of Community Tourism Impacts. Annals of Tourism Research, 32(4): 1056-1076.

ANDRIOTIS, K., \& VAUGHAN, R. D. (2003). "Urban Residents' Attitudes Toward Tourism Development: The Case of Crete". Journal of Travel Research, 42(2): 172-185.

AP, J. (1997). "Residents' Perceptions on Tourism İmpacts". Annals of Tourism Research, 19(4): 665-690.

ARSLANALP, M. (2019). "Yoldaki Kadınlar: Gezi Anlatılarında Toplumsal Cinsiyet ve Sınırları Aşmak". İstanbul Üniversitesi Sosyal Bilimler Enstitüsü, (Yüksek Lisans Tezi), İstanbul .

ASLANTÜRK, E., \& UNUR, K. (2019). "Yalnız Seyahat Eden Kadınların Seyahat Deneyimleri". Seyahat ve Otel İşletmeciliği Dergisi, 16(3): 493-514.

AVCIKURT, C. (2007). "Turizm Sosyolojisi; Turist-Yerel Halk Etkileşimi". Detay Yayıncılık, Ankara.

AY, M., \& ÖZEL, Ç. H. (2019). "Postmodern Turist Deneyimi: Motosikletli Kadın Gezginler Üzerine Bir Değerlendirme". Nevşehir Hacı Bektaş Veli Üniversitesi SBE Dergisi, 9(2): 630-645.

AYAZ, N., \& PARLAK, U. (2019). "Kırsal Alanlarda Yaşayan Yerel Halkın Kişilik Tipleri ve Turizm Algisı". Journal of History Culture and Art Research, 8(3): 480-494.

AYAZLAR, R. A., \& AYAZLAR, G. (2016). "Yerel Halkın Turizmin Etkilerine Yönelik Tutumunda Aidiyet Duygusu ve Yaşam Tatmininin Rolü". Atatürk Üniversitesi Sosyal Bilimler Enstitüsü Dergisi, , 20(4): 1451-1470.

BOĞAN, E., \& SARIIŞIK, M. (2016). "Yerel Halkın Turizm Faaliyetine Yönelik Görüş Ve Algılamalarının Belirlenmesi Üzerine Alanya'da Bir Araştırma". Kastamonu Üniversitesi İktisadi ve İdari Bilimler Fakültesi Dergisi, 12(2): 325-342.

BRITISH AIRWAYS. (2018, 10 10). "(Don't) Come Fly With Me. 05 11, 2021 tarihinde British Airways": https://mediacentre.britishairways.com/pressrelease/details/86/2018247/10174 adresinden alınd.

BROUGHAM, J., \& BUTLER, R. (1981). "A Segmentation Analysis of Resident Attıtudes". Annals of Tourism Research, 8(4): 569-590.

BROWN, L., \& OSMAN, H. (2017). "The Female Tourist Experience in Egypt as an Islamic Destination". Annals of Tourism Research, 63: 12-22.

BRUNT, P., \& COURTNEY, P. (1999). "Host Perceptions of Sociocultural Impacts". Annals of Tourism Research, 26(3): 493-515.

BÜYÜKÖZTÜRK, Ş. (2002). "Faktör Analizi: Temel Kavramlar ve Ölçek Geliştirmede Kullanımı". Kuram ve Uygulamada Eğitim Yönetimi Dergisi, 32(32): 470-483. 
BÜYÜKÖZTÜRK, Ş., ÇAKMAK, E. K., AKGÜN, Ö. E., KARADENİ, Ş., \& DEMİREL, F. (2020). "Eğitimde Bilimsel Araştırma Yöntemleri". Pegem Akademi, Ankara.

CENGIZ, E., \& KIRKBİR, F. (2007). "Yerel Halk Tarafindan Algilanan Toplam Turizm Etkisi ile Turizm Desteği Arasındaki İlişkiye Yönelik Yapısal Bir Model Önerisi". Anadolu Üniversitesi Sosyal Bilimler Dergisi, 7(1): 19-37.

CHIANG, C. Y., \& JOGARATNAM, G. (2005). "Why Do Women Travel Solo for Purposes of Leisure?" Journal of Vacation Marketing, 12(1): 59-70.

CHOI, H. S. C., \& SIRAKAYA, E. (2005). "Measuring Residents' Attitude Toward Sustainable Tourism: Development of Sustainable Tourism Attitude Scale". Journal of Travel Research, 43(4): 380-394.

ÇABUK, S., NAKIBOĞLU, B., \& CANOĞLU, M. (2013). "Algılanan Otel İmajı ve Hizmet Kalitesi ile Tekrar Satın Alma Niyeti Arasındaki İlişkiler". Anatolia: Turizm Araştırmaları Dergisi, 24(1): 96-108.

ÇALIŞKAN, U. "Turizmin Yerel Halk Üzerindeki Etkileri ve Kuşadası İlçesi Uygulaması". Yüksek Lisans Tezi, Dokuz Eylül Üniversitesi, 2008.

ÇELIK, M., \& GÖLPEK KARABABA, A. (2018). "Girişimcilik Niyetlerinin Demografik Faktörlere Göre İncelenmesi". Girişimcilik ve Kalkınma Dergisi, 13(1): 57-67.

ÇELİKKANAT, N., \& GÜÇER, E. (2014). "Yerel Halkın Turizme Bakış Açısı: Bodrum İlçesi Örneği". Gazi Üniversitesi Turizm Fakültesi Dergisi, 1(15): 272-289.

ÇETİN, A., \& ŞENTÜRK, M. (2016). "Bilgi Paylaşma Davranışının Planlı Davranış Teorisi ve Sosyal Değişim Teorisi Bağlamında İncelenmesi: Dermatologlar Üzerine Ampirik Bir Araştırma". Ege Akademik Bakış Dergisi, 16(2): 241-256.

ÇETİN, C., \& KARALAR, S. (2016). "X, Y ve Z Kuşağı Öğrencilerin Çok Yönlü ve Sınırsız Kariyer Algıları Üzerine Bir Araştırma". Yönetim Bilimleri Dergisi, 14(28): 157-197.

ÇETINEL, E., \& ERSOY YILMAZ, S. (2016). "Feminist Teori: Yönetim Ve Organizasyon Alanına Eleştirel Bir Yaklaşım". Çankırı Karatekin Üniversitesi İktisadi ve İdari Bilimler Fakültesi Dergisi, 6(2): 119-148.

ÇETINKAYA BOZKURT, Ö. (2014). "Planlanmış Davranış Teorisi Çerçevesinde Öğrencilerin Girişimci Olma Niyetlerinin İncelenmesi". Ekonomi ve Yönetim Araştırmaları Dergisi, 3(1): 27-47.

ÇOLAK, E., \& TAYFUN, A. (2017). "Çamlıhemşin İlçe Merkezinde Yerli Halkın Turizme İlişkin Görüşleri". Journal of Tourism and Gastronomy Studies, 5(4): 581-598.

DENiZ, M. (2016). "Kayaağıl Köyünde (Uşak) Turizmin Etkileri Üzerine Yerel Halkın Turizm Algısı". Electronic Turkish Studies, 11(18): 57-78.

DIEDRICH, A., \& GARCI'A-BUADES, E. (2009). "Local Perceptions of Tourism As Indicators of Destination Decline". Tourism Management, 30(4): 512-521.

DOĞAN, H., \& ÜNGÜREN, E. (2012). "Yerel Halkın Isparta Turizmine Yönelik Görüşleri Üzerine Bir Araştırma". Süleyman Demirel Üniversitesi İktisadi ve İdari Bilimler Fakültesi Dergisi, 17(1): 103-122. 
DUANTRAKOONSIL, T., REID, E. L., \& LEE, H. Y. (2019). "Foreing Travellers' Museum Motivation and Museum Service Quality in Thailand: Comparison of Solo Female and General Travellers". Journal of Community Development Research (Humanities and Social Sciences), 12(1): 48-59.

EMEKLİ, G. (2006). "Coğrafya, Kültür ve Turizm: Kültürel Turizm". Ege Coğrafya Dergisi, 15(1-2): 51-59.

ERCAN, F. (2019). "Karadeniz Ereğli İlçesinde Yerel Halkın Turizmin Gelişimine Yönelik Tutum ve Algılarını Belirlemeye Yönelik Bir Araştırma". Uluslararası Yönetim İktisat ve İşletme Dergisi, 15(2): 612-628.

ERCAN, İ., \& KAN, İ. (2004). "Ölçeklerde Güvenirlik ve Geçerlik". Uludağ Üniversitesi Tıp Fakültesi Dergisi, 30(3): 211-216.

ERIŞTİ, S. D., ULUUYSAL, B., \& DİNDAR, M. (2013). "Görsel Algı Kuramlarına Dayalı Etkileşimli Bir Öğretim Ortamı Tasarımı ve Ortama İlişkin Öğrenci Görüşleri". Anadolu Journal of Educational Sciences International, 3(1): 47-66.

ERKILIÇ, E. (2019). "Yerel Halkın Turizm Algısı ve Turizmin Gelişimine Yönelik Tutumları: Rize Örneği". International Journal of Contemporary Tourism Research, 3(1): 66-82.

ERTEN, S. (2002). "Kız ve Erkek Öğrencilerin Evde Enerji Tasarrufu Yapma Davranış Amaçlarının Planlanmış Davranış Teorisi Yardımıyla Araştırılması". Hacettepe Üniversitesi Eğitim Fakültesi Dergisi, 22(22): 67-73.

ESHLIKI, S. A., \& KABOUDI, M. (2012). "Community Perception of Tourism Impacts and Their Participation in Tourism Planning: A Case Study of Ramsar, Iran". ProcediaSocial and Behavioral Sciences, 36: 333-341.

F. ÖZKÖK And M. KORKMAZ, (2015). "Tek Başına Seyahat Eden Kadın Turistlerin Seyahat Kisitlayıc1ları," 16. Ulusal turizm Kongresi: 1671-1688.

GARCÍA, F. A., VÁZQUEZ, A. B., \& MACÍAS, R. C. (2015). "Resident's Attitudes Towards The Impacts of Tourism". Tourism Management Perspectives, 13: 33-40.

GAZELOĞLU, C., \& ERKILIÇ, E. (2020). "Bilimsel Araştırmalarda Temel Örnekleme Yöntemleri". Detay Yayıncılık, Ankara.

GETZ, D. (1994)."Residents' Attitudes Towards Tourism". Tourism Management, 15: 247258.

GÖKDEMIR, S., \& HACIOĞLU, N. (2018). "Turist Rehberlerinde Tükenmişlik ve Meslekten Ayrılma Niyeti". Balıkesir Üniversitesi Sosyal Bilimler Enstitüsü Dergisi, 21(39): 511-541.

GRAY, J. M., \& WILSON, M. A. (2009). "The Relative Risk Perception of Travel Hazards". Environment and Behavior, 41(2): 185-204.

GÜNEŞ, N. "Yerel Halkın Turizm Algısı ve Turizme Katılımı:Antalya Konyaaltı ve Kepez İlçesi Örneği". Yüksek Lisans Tezi, Akdeniz Üniversitesi, 2014. 
HAO, J. S., \& HAR, C. O. (2014). "A Study of Preferences of Business Female Travelers on the Selection of Accommodation". Procedia - Social and Behavioral Sciences, 144: 176-186.

HARRILL, R., \& POTTS, T. D. (2003). "Tourism Planning in Historic Districts: Attitudes Toward Tourism Development in Charleston". Journal of The American Planning Association, 69(3): 233-244.

HASTINGS, B., \& HIKIDA, L. (1997). "PATA Communications. Women Travellers: A New Growth Market": https://www.hotelonline.com/News/PressReleases/PataWomenTravellers_Nov1997.html\#: :text=Over $\% 20$ the $\% 20$ past $\% 20$ five $\% 20$ years, Taipei\%2C\%20Hong\%20Kong\%20and\%20Sing apore, 05.03.2021.

INBAKARAN, R., \& JACKSON, M. (2005). "Marketing Regional Tourism: How Better to Target and Address Community Attitudes to Tourism". IAHS Proceedings and Report, 11(3): 284-291.

IŞIK, C., \& ÇALKIN, Ö. (2016). "Yerel Halkın Turizm Algsı: TRA2 Bölgesi Analizi". IUJEAS, 1(2): 19-48.

JAFARI, J. (1986). "A Systemic View of Sociocultural Dimensions of Tourism". In President's Commission on American Outdoors, Tourism. Washington DC : 33-50.

JANG, S., BAI, B., HU, C., \& WU, C. M. E. (2009). "Affect, Travel Motivation and Travel Intention: A Senior Market". Journal of Hospitality \& Tourism Research, 33(1): 5173.

JOHNSON, J. D., SNEPENGER, D. J., \& AKİS, S. (1994). "Residents' Perceptions of Tourism Development". Annals of Tourism Research, 21(3): 629-642.

JORDAN, F., \& AITCHISON, C. (2008). "Tourism and The Sexualisation of The Gaze: Solo Female Tourists' Experiences of Gendered Power, Surveillance and Embodiment". Leisure Studies, 27(3): 329-349.

JORDAN, F., \& GIBSON, H. (2005). "We're Not Stupid... But We'll Not Stay Home Either: Experiences of Solo Women Travelers". Tourism Review International, 9(2): 195211.

JUANLTA C, L., \& WAR, T. (1986). "Resident Attitudes to Turism Impacts in Hawaii". Annals of Tourism Research, 13(2): 193-214.

JUROWSKI, C., UYSAL, M., \& WILLIAMS, D. R. (1997). "A Theoretical Analysis of Host Community Resident Reactions to Tourism". Journal of Travel Research, 36(2):3-11.

KABA, B., \& EMEKLİ, G. (2018). "Turizmde Yükselen Bir Eğilim: Yalnız Seyahat Eden Kadın Gezginler (Türkiye Örneği)". Ege Coğrafya Dergisi, 27(2): 111-126.

KAHRAMAN, S. D. (2010). "Kadınların Toplumsal Cinsiyet Eşitsizliğine Yönelik Görüşlerinin Belirlenmesi". Dokuz Eylül Üniversitesi Hemşirelik Yüksekokulu Elektronik Dergisi, 3(1): 30-35. 
KALAV, A. (2012). "Namus ve Toplumsal Cinsiyet". Mediterranean Journal of Humanities, 2(2): 151-163.

KARAGÖZ, D., IŞIK, C., DOGRU, T., \& ZHANG, L. (2021). "Solo Female Travel Risks, Anxiety and Travel Intentions: Examining The Moderating Role of Online Psychological-Social Support". Current Issues in Tourism, 24(11): 1595-1612

KARAKAŞ, A., \& ŞENGÜN, H. İ. (2017). "Yerel Halkın Turizm Faaliyetlerine Yönelik Tutumları". Bartın Üniversitesi İktisadi ve İdari Bilimler Fakültesi Dergisi, 8(15): 183-202.

KARASAR, N. (2005). "Bilimsel Araştıma Yöntemi". Nobel Yayınları, Ankara.

KERVANKIRAN, İ., \& BULUT, E. (2015). "Antalya İli Turizminin Gelişimini Ve Etkilerini Yerel Halk Nasıl Değerlendirmektedir?" Türk Coğrafya Dergisi, (65): 35-46.

KERVANKIRAN, İ., \& İLBAN, K. (2019). "Türkiye'den Turizm Amacıyla Yurtdışına Giden Kadınların Seyahat Motivasyonları". 20. Ulusal Turizm Kongresi, Anadolu Üniversitesi, Eskişehir.

KESKIN, E., \& ÇONTU, M. (2011). "Mustafapaşa (Sinasos) Kasabasında Yaşayan Halkın Turizme Bakış Açısını Belirlemeye Yönelik Bir Alan Araştırması". Aksaray Üniversitesi İktisadi ve İdari Bilimler Fakültesi Dergisi, 3(2): 37-55.

KHAN, S. (2011). "Gendered Leisure: Are Women More Constrained in Travel for Leisure?" Tourismos: An International Multidisciplinary Journal of Tourism, 6(1): 105-121.

KILIÇLAR, A., \& ALDOĞAN ŞENOL, F. (2019). "Üçüncü Yaş Turistlerin Seyahat Motivasyonu ile Seyahat Memnuniyeti Arasındaki İlişki". Journal of Tourism and Gastronomy Studies, 7(4): 3249-3261.

KING, B., PIZAM, A. \& MILMAN, A. (1993). "Social Impacts of Tourism: Host Perceptions". Annals of Tourism Research, 20(4): 650-665.

KORÇA, P. (1998). "Resident Perceptions of Tourism in A Resort Town". Leisure Sciences, 20(3): 193-212.

KORKMAZ, M. (2018). "Yerel Halkın Kadın Turistler Karşı Bakış Açısının Toplumsal Cinsiyet Eşitliği Bağlamında İncelenmesi: Gökçeada Örneği". Journal of Life Economics, 6(1): 33-58.

KULABER, İ. "Tarihteki Öncü 10 Kadın Gezgin". obilet.com: https://blog.obilet.com/tarihteki-oncu-10-kadin-gezgin, 05.08.2018.

KUTLUK BOZKURT, A., \& AVCIKURT, C. (2019). "Planlanmış Davranış Teorisi ile Yerli Y Kuşağ1 Turistlerin Destinasyon Tercih Etme Niyetinin Belirlenmesi". Afyon Kocatepe Üniversitesi Sosyal Bilimler Dergisi, 21(4): 1294-1307.

KÜÇÜK, E. (2011). "Planlanmış Davranış Teorisi Çerçevesinde Mali Müşavir (SMMM) Olma Niyetinin Altında Yatan Faktörlerin Analizi". ZKÜ Sosyal Bilimler Dergisi, 7(14): 145-162.

LANKFORD, S. V., \& HOWARD, D. R. (1994). "Developing A Tourism Impact Attitude Scale". Annals of Tourism Research, 21(1): 121-139. 
LATANE, B. (1981). "The Psychology of Social Impact". American Psychologist, 36(4): 343356.

LEPP, ANDREW. (2007). "Residents' Attitudes Towards Tourism in Bigodi Village", Uganda. Tourism Management, 28(3): 876-885.

LIU, J., \& VAR, T. (1986). "Resident Attitudes Toward Tourism Impacts in Hawaii". Annals of Tourism Research, 13(2): 193-214.

LYONS, B. J., \& SCOTT, B. A. (2012). "Integrating Social Exchange and Affective Explanations For The Receipt of Help And Harm: A Social Network Approach". Organizational Behavior And Human Decision Processes, 117(1): 66-79.

MCNAMARA, K. E., \& PRIDEAUX, B. (2010). "A Typology of Solo Independent Women Travellers". International Journal of Tourism Research, 12(3): 253-264.

MILMAN, A., \& PIZAM, A. (1988). "Social Impact of Tourism on Central Florida". Annals of Tourism Research, 15 (2): 191-204.

MOUTINHO, L. (1987). "Consumer Behaviour in Tourism". European Journal of Marketing, 21(10): 5-44.

MUTLU, H. M., ÇEVİKER, A., \& ÇİRKİN, Z. (2011). "Tüketici Entrosentrizmi ve Yabancı Ürün Satın Alma Niyeti: Türkiye ve Suriye Üzerine Karşılaştırmalı Analiz". Sosyoekonomi Dergisi, 14(14): 51-74.

NETTLE, D. (1999). "Using Social Impact Theory to Simulate Language Change". Lingua, 108(2-3): 95-117.

OĞUZBALABAN, G. (2017). "Türkiye'de Yerel Halkın Turizme ve Turizmin Etkilerine Yönelik Alg1 ve Tutumlarına İlişkin Yazın Taraması". Uluslararası Sosyal Araştırmalar Dergisi, 10(51): 1321-1329.

OSMAN, H., BROWN, L., \& PHUNG, T. M. (2019). "The Travel Motivations and Experiences of Female Vietnamese Solo Travellers". Tourist Studies, 20(2): 1-20.

ÖTER, Z., \& ÖZDOĞAN, O. N. (2005). "Kültür Amaçlı Seyahat Eden Turistlerde Destinasyon İmaj1: Selçuk-Efes Örneği". Anatolia: Turizm Araştırmaları Dergisi, 16(2): 127-138.

ÖZDAMAR, K. (2001). "Paket Programlar ve İstatistiksel Veri Analizi (Çok Değişkenli Analizler)". Kaan Yayınları, Eskişehir.

ÖZDAMAR, M. "Turizmin Gelişmişlik Düzeyine Göre Yerel Halkın Turizm Algısı: AlanyaErdek ve Kalecik'te Karşılaştırmalı Bir Araştırma". Doktora Tezi, Mersin Üniversitesi, 2019.

ÖZKÖK, F., \& CESUR, M. (2015). "Tek Başına Seyahat Eden Kadın Turistlerin Seyahat Kisıtlayıcıları". Detay Yayıncılık, Ankara.

ÖZSAÇMACI, B. (2018). "Yeşil Pazarlama Faaliyetlerinin Yeşil Marka Farkındalığı ve Tüketici Satın Alma Niyeti Üzerindeki Aracılık Etkisi". Business and Economics Research Journal, 9(4): 945-960. 
ÖZTÜRK, M., \& BAYAT, M. (2011). "Uluslararası Turizm Hareketlerinde Sağlık Turizminin Rolü ve Kalite Çalışmalarının Önemi Bir Literatür Çalışması". Kahramanmaraş Sütçü İmam Üniversitesi İktisadi ve İdari Bilimler Fakültesi Dergisi, 1(2): 135-156.

PAN, Y., \& JACKSON, R. T. (2008). "Ethnic Difference in the Relationship Between Acute Inflammation and Serum Ferritin in US Adult Males". Epidemiology and Infection, 136(3): 421-431.

PEKINNER, A. B. "Yalnız Seyahat Eden Kadınların Motivasyon ve Deneyimleri: Diyarbakır'ı Ziyaret Eden Kadınlar Üzerine Bir Araştırma". Yüksek Lisans Tezi, Batman Üniversitesi, 2019.

PERDUE, R. R., LONG, P. T., \& ALLEN, L. (1987). "Rural Resident Tourism Perceptions and Attitudes". Annals of Tourism Research, 14(3): 420-429.

PERDUE, R. R., LONG, P. T., \& ALLEN, L. (1990). "Resident Support for Tourism Development". Annals of Tourism Research, 17 (4): 586-599.

REISINGER, Y., \& CROTTS, J. C. (2010). "The Influence of Gender on Travel Risk Perceptions, Safety and Travel Intentions". Tourism Analysis, 14(6): 793-807.

RİZE İL KÜLTÜR VE TURİZM MÜDÜRLÜĞÜ, (2019). http://www.rizekulturturizm.gov.tr, 5.30.2021.

SAATCI, G. "Kültürlerarası Turist Tutumları: Bütünleşik Tehdit Teorisi Çerçevesinde Bir Araştırma". Doktora Tezi, Balıkesir Üniversitesi, 2016.

SAĞLIK ÖZÇAM, D., \& BİLGİN, F. Z. (2012). "Satınalma Davranışında Reklamın ve Reklam Türlerinin Önemi Ve Etik Algısı". Organizasyon ve Yönetim Bilimleri Dergisi, 4(1): 65-74.

SARAÇ, M., \& KAHYAOĞLU, M. B. (2011). "Bireysel Yatırımcıların Risk Alma Eğilimine Etki Eden Sosyo-Ekonomik ve Demografik Faktörlerin Analizi". BDDK Bankacılık ve Finansal Piyasalar Dergisi, 5(2): 135-157.

SARUHAN, Ş. C., \& ÖZDEMİRCİ, A. (2020). "Bilim, Felsefe ve Metodoloji". Beta Yayıncılık, İstanbul.

SEOW, D., \& BROWN, L. (2018). "The Solo Female Asian Tourist". Current Issues in Tourism, 21(10): 1187-1206.

SERT, A. N. (2019). "Üçüncü Yaş Yerli Turistlerin Seyahat Kısıtları ve Motivasyonları Üzerine Bir Araştırma". Selçuk Üniversitesi Sosyal Bilimler Enstitüsü Dergisi, (42): 200-211.

SHARPLEY, R. (2014). "Host Perceptions of Tourism: A Review of The Research". Tourism Management, 42: 37-49.

SOLMAZ, C. (2014). "Yerel Halkın Bölge Turizmine Bakış Açısının Belirlenmesi: Burdur'da Bir Araştırma". Mehmet Akif Ersoy Üniversitesi Sosyal Bilimler Enstitüsü Dergisi, 6(10): 91-105.

SOLMAZ, S. A. (2019). "Turizmin Doğuşu: Sosyolojik Bir Olgu Olarak Turizm Nasıl Ortaya Çıktı?" Journal of Social, Humanities and Administrative Sciences, 5(19): 867-882. 
SU, C.-P., \& WU, T.-C. (2020). "The Dark Side of Solo Female Travel: Negative Encounters with Male Strangers". Leisure Sciences an Interdisciplinary Journal, 42(3-4): 375-392.

SÜRAL, S., \& SARITAŞ, E. (2015). "Pedagojik Formasyon Programına Katılan Öğrencilerin Öğretmenlik Mesleğine Yönelik Yeterliklerinin İncelenmesi". Mersin Üniversitesi Eğitim Fakültesi Dergisi, 11(1): 62-75.

ŞAHİN, B., \& TAŞKAYA, S. (2010). "Sağlık Çalışanlarının Örgütsel Adalet Algıları". Hacettepe Sağlık İdaresi Dergisi, 13(2): 85-114.

ŞENGÜL, S. (2018). "Destinasyon Gastronomi Marka Değeri Bileşenlerinin Seyahat Niyeti Üzerine Etkisi". AİBÜ Sosyal Bilimler Enstitüsü Dergisi, 18(18): 1-22.

ŞEŞEN, H., \& BASIM, H. N. (2012). "Demografik Faktörler ve Kişiliğin Girişimcilik Niyetine Etkisi: Spor Bilimleri Alanında Öğrenim Gören Üniversite Öğrencileri Üzerine Bir Araştırma". Ege Akademik Bakış, 12(Özel Sayı): 21-28.

ŞİMŞEK, A. (2012). Sosyal Bilimlerde Araştırma Yöntemleri. Anadolu Üniversitesi Yayınları, Eskişehir.

TANRIVERDİ, H., KOÇASLAN, G., \& OSMANOĞLU TAŞTAN, N. (2018). "Psikolojik Şiddet Algısı, Tükenmişlik Sendromu Ve İşten Ayrılma Niyeti Arasındaki İlişki: Banka Çalışanları Üzerinde Bir Araştırma". Yöntem ve Ekonomi Dergisi, 25(1): 113131.

TAŞTAN, C. (2019). "Tek Başına Seyahate Çıkma Konusunda Erkekleri ‘Sollayan’ Kadınlar". https://listelist.com/tek-basina-seyahat-kadinlar, 05. 11. 2021.

TAYTAK, M. (2016). Vergi Kültürünü Belirleyen Faktörler ve Mükelleflerin Demografik Özelliklerinin Vergi Kültürü Üzerindeki Etkisi". İnsan ve Toplum Bilimleri Araştırmaları Dergisi, 5(7): 1933-1957.

TDK. (2019). "Türk Dil Kurumu Sözlükleri". Türk Dil Kurumu: https://sozluk.gov.tr.

TEYE, V., SÖNMEZ, S. F., \& SIRAKAYA, E. (2002). "Residents' Attitudes Toward Tourism Development". Annals of Tourism Research, 29(3): 668-688.

THOMAS, T. K., \& MURA, P. (2019). "The 'Normality of Unsafety'- Foreign Solo Female Travellers in India". Tourism Recreation Research, 44(1): 33-40.

TILlEY, S., \& HOUSTON, D. (2016). "The Gender Turnaround: Young Women Now Travelling More Than Young Men". Journal of Transport Geography, 54: 349-358.

TURAN, A. H. (2011). "İnternet Alışverişi Tüketici Davranışını Belirleyen Etmenler: Planlı Davranış Teorisi (TPB) ile Ampirik Bir Test". Doğuş Üniversitesi Dergisi, 12(1): 128143.

TUYED. "Yalnız" Turist, Yalnız Değilsin"!... http://www.tuyed.org.tr/yalniz-turist-yalnizdegilsin, 05.12.2016.

TÜİK. (2020). "Adrese Dayalı Nüfus Kayıt Sistemi Sonuçları". Türkiye İstatistik Kurumu: https://www.tuik.gov.tr, 02.11.2020. 
TUİK. (2021). "Türkiye İstatistik Kurumu". https://data.tuik.gov.tr/: https://data.tuik.gov.tr/ 02. 12. 2021.

TÜRKER, N., SELÇUK, Ş., \& ÖZYILDIRIM, A. (2016). "Turizmin Yerel Halkın Yaşam Kalitesi Üzerine Etkisi: Safranbolu Örneği". Karabük Üniversitesi Sosyal Bilimler Enstitüsü Dergisi, 6(1): 1-13.

TÜRKMEN, S., \& OFLAZ, M. B. (2018). "Yerel Halkın Yazlıkçılara Yönelik Algıları". Mustafa Kemal Üniversitesi Sosyal Bilimler Enstitüsü Dergisi, 15(41): 185-201.

URAL, A., \& KILIÇ, İ. (2018). "Bilimsel Araştırma Süreci ve SPSS ile Veri Analizi". Detay Yayıncilık, Ankara.

UŞTU, H., \& TÜMKAYA, S. (2017). "Sınıf Öğretmenlerinin Mesleki Bağlılık, İşten Ayrılma Niyeti ve Bazı Sosyo-Demografik Özelliklerinin Örgütsel Bağlılı̆̆ Y Yordama Düzeylerinin İncelenmesi". Elementary Education Online, 16(3): 1262-1274.

UZUN, T., \& AYIK, A. (2016). "Okul Müdürlerinin İletişim Becerileri İle Öğretmenlerin Genel ve Örgütsel Sinizm Tutumları Arasındaki İlişkilerin İncelenmesi". Mersin Üniversitesi Eğitim Fakültesi Dergisi, 12(2): 672-688.

ÜLKÜ, A., \& BİŞKİN, F. (2020). "Destinasyon Kişiliği ve Benlik Uyumunun Turistlerin Davranışsal Niyetleri Üzerine Etkisi". Selçuk Üniversitesi Sosyal Bilimler Enstitüsü Dergisi, (43): 127-142.

VODEB, K., \& VD. (2021). Residents Perceptions of Tourism Impacts and Support for Tourism Development". Tourism and Hospitality Management, 27(1): 143-166.

WARD, C., \& BERNO, T. (2011). "Beyond Social Exchange Theory: Attitudes Toward Tourists". Annals of Tourism Research, 38(4): 1556-1569.

WEAVER, D. B., \& LAWTON, L. J. (2001). "Resident Perceptions in the Urban-Rural Fringe". Annals of Tourism Research, 28(2): 439-458.

WIILIAMS, B., ONSMAN, A., \& BROWN, T. (2010). "Exploratory Factor Analysis: A fivestep Guide for Novices ". Australasian Journal of Paramedicine: 8(3).

WILSON, E. (2004). A'journey of Her Own'?: The İmpact of Constraints on Women's Solo Travel (Doctoral Dissertation, Griffith University).

WILSON, E., \& LITTLE, D. E. (2008). "The Solo Female Travel Experience: Exploring The 'Geography of Women's Fear". Current Issues in Tourism, 11(2): 167-186.

YANG, E. C., KHOO-LATTIMMORE, C., \& ARCODİA, C. (2018). "Power and Empowerment: How Asian Solo Female Travellers Perceive and Negotiate Risks". Tourism Management, 68: 32-45.

YAŞLIOĞLU, M. M. (2017). "Sosyal Bilimlerde Faktör Analizi ve Geçerlilik: Keşfedici ve Doğrulayıcı Faktör Analizlerinin Kullanılması". Istanbul University Journal of the School of Business, 46(Özel Say1): 74-85.

YAZICI, G. "Himalayalar’ın Zirvelerine “Kadınlara Oy Hakkı” Mücadelesini Taşıdı: Fanny Bullock Workman". Bilim ve

Gelecek: 
https://bilimvegelecek.com.tr/index.php/2018/03/16/himalayarin-zirvelerinekadinlara-oy-hakki-mucadelesini-tasidi-fanny-bullock-workman, 16.03.2018.

YILDIZ, B., \& POLAT, E. (2016). "Yerel Halkın Eskişehir'de Düzenlenen Festivallerin Etkilerine Yönelik Algıları". Local. Journal of Tourism and Gastronomy Studies, 4(2): 40-62.

YILDIZ, D., \& UZUNSAKAL, E. (2018). "Alan Araştırmalarında Güvenilirlik Testlerinin Karşılaştırması ve Tarımsal Veriler Üzerine Bir Araştırma". Uygulamalı Sosyal Bilimler Dergisi, 2(1): 14-28.

YILDIZ, E. Ç., \& ÇALIŞKAN, U. (2018). "Turizme Yakın ama Turizmden Uzak Yerel Halkın Turizme Bakışı: Muğla Menteşe İlçesi Örneği". Trakya University Journal of Social Science, 20(2): 223-243.

YING, T. J., AWANG, K. W., \& BOJEI, J. (2017). "Generation Y Malaysian Women's Perception Towards Solo Travel". Asia-Pacific Journal of Innovation in Hospitality and Tourism, 6(2): 45-54.

YOON, Y., GURSOY, D., \& CHEN, J. S. (2001). "Validating A Tourism Development Theory With Structural Equation Modeling". Tourism Management, 22(4): 363-372.

YÜKSEL, M. (2018). "İşgörenlerin Politik Becerilerinin Yöneticilerin Görev Performans1 Değerlendirmeleri Üzerindeki Etkisi: Sosyal Etki Kuramı Açısından Bir Değerlendirme". Ege Akademik Bakış, 18(3): 445-455.

ZAMAN, M., \& BİRİNCİ, S. (2009). "Kaçkar Dağları'nda Alternatif Bir Turizm Aktivitesi: Heliski (Dă̆ Kayağı)". Atatürk Üniversitesi Sosyal Bilimler Enstitüsü Dergisi, 13(2): $33-46$. 